\title{
Rodlike Bimetallic Ruthenium and Osmium Complexes Bridged by Phenylene Spacers. Synthesis, Electrochemistry, and Photophysics
}

\author{
Steve Welter,${ }^{\dagger}$ Nunzio Salluce, ${ }^{\ddagger}$ Arianna Benetti,${ }^{\dagger}$ Nicolette Rot, ${ }^{\dagger}$ Peter Belser, ${ }^{\ddagger}$ Prashant Sonar,,$\$$ \\ Andrew C. Grimsdale, $\$$ Klaus Mullen, $\$$ Martin Lutz," Anthony L. Spek," and Luisa De Cola ${ }^{*, \dagger}$ \\ Molecular Photonics Materials, University of Amsterdam, Nieuwe Achtergracht 166, 1018 WV \\ Amsterdam, The Netherlands, University of Fribourg Pérolles, CH-1700 Fribourg, Switzerland, \\ Max-Planck-Institut für Polymerforschung, Ackermannweg 10, D-55128 Mainz, Germany, and \\ Bijvoet Center for Biomolecular Research, Department of Crystal and Structural Chemistry, \\ Utrecht University, Padualaan 8, 3584CH Utrecht, The Netherlands
}

Received November 30, 2004

\begin{abstract}
In the search for light-addressable nanosized compounds we have synthesized 10 dinuclear homometallic trisbipyridyl complexes of linear structure with the general formula $\left[\mathrm{M}(\mathrm{bpy})_{3}-\mathrm{BL}-\mathrm{M}(\mathrm{bpy})_{3}\right]^{4+}[\mathrm{M}=\mathrm{Ru}(\mathrm{II})$ or $\mathrm{Os}(\mathrm{II}) ; \mathrm{BL}=$ polyphenylenes $\left(2,3,4\right.$, or 5 units) or indenofluorene; bpy $=2,2^{\prime}$-bipyridine]. By using a "chemistry on the complex" approach, different sizes of rodlike systems have been obtained with a length of 19.8 and $32.5 \AA$ for the shortest and longest complex, respectively. For one of the ruthenium precursors, $\left[\right.$ Rubpy-ph $\left.-\mathrm{Si}\left(\mathrm{CH}_{3}\right)_{3}\right]\left[\mathrm{PF}_{6}\right]_{2}$, single crystals were obtained by recrystallization from methanol. Their photophysical and electrochemical properties are reported. All the compounds are luminescent both at room and low temperature with long excited-state lifetimes due to an extended delocalization. Nanosecond transient absorption showed that the lowest excited state involves the chelating unit attached to the bridging ligand. Electrochemical data indicated that the first reduction is at a slightly more positive potential than for the reference complexes $\left[M(b p y)_{3}\right]^{2+}(M=R u$, Os). This result confirms that the best acceptor is the bipyridine moiety connected to the conjugated spacers. The role of the tilt angle between the phenylene units, in the two series of complexes, for the ground and excited states is discussed.
\end{abstract}

\section{Introduction}

Functional molecular components able to be addressed with an external stimulus are the key structures for building up electronic circuits and devices. Molecular wires, ${ }^{1-4}$ diodes, ${ }^{5-7}$ and transistors ${ }^{8,9}$ are only a few of the desired

* To whom correspondence should be addressed. Fax: +31205256456. E-mail: 1dc@science.uva.nl.

$\dagger$ University of Amsterdam. Nieuwe Achtergracht 166, 1018 WV Amsterdam, The Netherlands, Fax: +31 20525 6456, ldc@science.uva.nl (L. De Cola).

University of Fribourg Pérolles, CH-1700 Fribourg, Switzerland.

$\S$ Max-Planck-Institut für Polymerforschung, Ackermannweg 10, D-55128 Mainz, Germany.

"Bijvoet Center for Biomolecular Research, Department of Crystal and Structural Chemistry, Utrecht University, Padualaan 8, 3584CH Utrecht, The Netherlands.

(1) Weiss, E. A.; Ahrens, M. J.; Sinks, L. E.; Gusev, A. V.; Ratner, M. A.; Wasielewski, M. R. J. Am. Chem. Soc. 2004, 126, 5577-5584.

(2) Chen, J.; Wang, W.; Klemic, J.; Reed, M. A.; Axelrod, B. W.; Kaschak, D. M.; Rawlett, A. M.; Price, D. W.; Dirk, S. M.; Tour, J. M.; Grubisha, D. S.; Bennett, D. W. In Molecular Electronics II; Annals of the New York Academy of Sciences, 2002; Vol. 960, pp 69-99.

(3) Mayor, M.; Buschel, M.; Fromm, K. M.; Lehn, J. M.; Daub, J. In Molecular Electronics II; Annals of the New York Academy of Sciences, 2002; Vol. 960, pp 16-28.

4706 Inorganic Chemistry, Vol. 44, No. 13, 2005 objects which recently have attracted a lot of attention. In many cases, conjugated systems have been developed leading to materials having a significant impact on emerging technologies for biotechnology, ${ }^{10}$ electronics, ${ }^{11}$ and optoelectronics. ${ }^{12}$ An attractive external input to trigger molecular

(4) Ratner, M. A.; Davis, B.; Kemp, M.; Mujica, V.; Roitberg, A.; Yaliraki, S. In Molecular Electronics: Science and Technology; Annals of the New York Academy of Sciences, 1998; Vol. 852, pp 22-37.

(5) Karzazi, Y.; Cornil, J.; Brédas, J. L. Nanotechnology 2003, 14, $165-$ 171.

(6) Karzazi, Y.; Cornil, J.; Brédas, J. L. Adv. Funct. Mater. 2002, 12, 787-794.

(7) Tour, J. M.; Rawlett, A. M.; Kozaki, M.; Yao, Y. X.; Jagessar, R. C.; Dirk, S. M.; Price, D. W.; Reed, M. A.; Zhou, C. W.; Chen, J.; Wang, W. Y.; Campbell, I. Chem.-Eur. J. 2001, 7, 5118-5134.

(8) Tans, S. J.; Dekker: C. Nature 2000, 404, 834-835.

(9) Adams, D. M.; Brus, L.; Chidsey, C. E. D.; Creager, S.; Creutz, C.; Kagan, C. R.; Kamat, P. V.; Lieberman, M.; Lindsay, S.; Marcus, R. A.; Metzger, R. M.; Michel-Beyerle, M. E.; Miller, J. R.; Newton, M. D.; Rolison, D. R.; Sankey, O.; Schanze, K. S.; Yardley, J.; Zhu, X. Y. J. Phys. Chem. B 2003, 107, 6668-6697.

(10) Tasch, S.; Brandstätter, C. Adv. Mater. 1997, 9, 33-36.

(11) Reichert, J.; Ochs, R.; Beckmann, D.; Weber, H. B.; Mayor, M.; Löhneysen, H. v. Phys. Rev. Lett. 2002, 88, 176804-1-176804-4.

(12) Yaliraki, S. N.; Kemp, M.; Ratner, M. A. J. Am. Chem. Soc. 1999, $121,3428-3434$.

10.1021/ic0483141 CCC: $\$ 30.25$

(C) 2005 American Chemical Society Published on Web 05/24/2005 
devices is light, and we expect a major development of systems capable of elaborating light for signal generation, processing, and storage. ${ }^{13}$ The large majority of the investigated systems are based on organic components, and only recently more research efforts have focused on modular systems containing transition-metal complexes. In particular, (electro)luminescent and redox-active metal-containing materials have been investigated with the aim of developing systems for applications such as optical signaling, ${ }^{14}$ laser damage protection, ${ }^{15,16}$ and light-emitting diodes (LEDs). ${ }^{17-20}$

Particularly important are systems where chromophoric or electron-addressable units can be positioned in such a way that the photoinduced processes can occur over long distances and/or along predetermined directions. To achieve and control these nanostructures, the systems must be rigid, modular, stable, and have a built-in vectorial functionality.

In recent years a lot of effort has been devoted to the design and synthesis of star-shaped and rod-type molecules. ${ }^{21}$ Electro- and photoresponsive units have been employed as the core of the system or as terminal moieties of the nanostructures. ${ }^{22,23}$ Organometallic complexes have been used as active components because of their unique photochemical, photophysical, and electrochemical properties. ${ }^{24}$ They have been held connected by several kinds of aromatic bridges, including oligothiophenes, ${ }^{25-30}$ oligophenylenevinylenes, ${ }^{31,32}$ poly(phenylene-ethynylenes), ${ }^{33-35}$ and diarylethenes. ${ }^{36-38}$

(13) Balzani, V.; Venturi, M.; Credi, A. Molecular devices and machines-A journey into the nanoworld; Wiley-VCH: Weinheim, 2003; Vol. 17.

(14) Buda, M.; Kalyuzhny, G.; Bard, A. J. J. Am. Chem. Soc. 2002, 124, 6090-6098.

(15) Gao, F. G.; Bard, A. J. Chem. Mater. 2002, 14, 3465-3470.

(16) Ran, F.-R. F.; Yang, J.; Dirk, S. M.; Price, D. W.; Kosynkin, D.; Tour, J. M.; Bard, A. J. J. Am. Chem. Soc. 2001, 123, 2454-2455.

(17) Welter, S.; Brunner, K.; Hofstraat, J. W.; De Cola, L. Nature 2003, $421,54-57$

(18) Wu, A.; Lee, J.; Rubner, M. F. Thin Solid Films 1998, 327-329, 663667.

(19) Rudmann, H.; Shimada, S.; Rubner, M. F. J. Am. Chem. Soc. 2002 124, 4918-4921.

(20) Lee, J.-K.; Yoo, D. S.; Handy, E. S.; Rubner, M. F. Appl. Phys. Lett. 1996, 69, 1686-1688

(21) Barigelletti, F.; Flamigni, L. Chem. Soc. Rev. 2000, 29, 1-12.

(22) Launay, J. P.; Coudret, C. In Electron Transfer in Chemistry; Balzani, V., Ed.; Wiley: Weinheim, 2001; Vol. 5, pp 3-43.

(23) Scandola, F.; Chiorboli, C.; Indelli, M. T.; Rampi, M. A. In Electron Transfer in Chemistry; Balzani, V., Ed.; Wiley: Weinheim, 2001; Vol. 3 , pp 337-403.

(24) Juris, A.; Balzani, V.; Barigelletti, F.; Campagna, S.; Belser, P.; von Zelewsky, A. Coord. Chem. Rev. 1988, 84, 85-277.

(25) Tracey, L.; Wolf, M. O. Coord. Chem. Rev. 2003, 246, 89-101.

(26) Pappenfus, T. M.; Mann, K. R. Inorg. Chem. 2001, 40, 6301-6307.

(27) Liu, Y.; De Nicola, A.; Reiff, O.; Ziessel, R.; Schanze, F. S. J. Phys. Chem. A 2003, 107, 3476-3485.

(28) Constable, E. C.; Housecroft, C. E.; Schofield, E. R.; Encinas, S.; Armaroli, N.; Barigelletti, F.; Flamigni, L.; Figgemeier, E.; Vos, J. G. Chem. Commun. 1999, 869-870.

(29) Encinas, S.; Flamigni, L.; Barigelletti, F.; Constable, E. C.; Housecroft, C. E.; Schofield, E. R.; Figgemeier, E.; Fenske, D.; Neuburger, M.; Vos, J. G.; Zehnder, M. Chem.-Eur. J. 2002, 8, 137-150.

(30) Harriman, A.; Mayeux, A.; De Nicola, A.; Ziessel, R. Phys. Chem. Chem. Phys. 2002, 4, 2229-2235.

(31) Shaw, J. R.; Webb, R. T.; Schmehl, R. H. J. Am. Chem. Soc. 1990, 112, 1117-1123.

(32) Encinas, S.; Barthram, A. M.; Ward, M. D.; Barigelletti, F.; Campagna, S. Chem. Commun. 2001, 277-278.

(33) El-ghayoury, A.; Harriman, A.; Ziessel, R. J. Phys. Chem. A 2000 , 104, 7906-7915.

(34) Harriman, A.; Khatyr, A.; Ziessel, R.; Benniston, A. C. Angew. Chem., Int. Ed. 2000, 39, 4287-4290.
The use of oligophenylene spacers between metal centers is particularly attractive. In fact, the synthetic control of the tilt angles between the phenylene units and differential substitution on the phenyl rings allow for tunability of the excited-state properties of the bridge and of the electronic interactions between the terminal units. ${ }^{39,40}$ For synthetic reasons related to solubility problems, in most of the studied systems the number of phenylene spacers has been limited to one, ${ }^{41,42}$ two, ${ }^{43-56}$ or three ${ }^{57}$ units. So far, only dinuclear compounds containing long alkyl chains on the phenylene bridge allowed the synthesis of long systems of more than three phenylene units, ${ }^{58}$ and only recently have more extended systems been reported. ${ }^{59}$ The introduction of solubilizing groups on one of the units leads to a tilt of the phenyl rings and consequently decreases the $\pi$-overlap between the aromatic units. In this paper we describe a series of bimetallic complexes (Chart 1) containing ruthenium or osmium tris-bipyridine units, $\mathrm{M}(\mathrm{bpy}){ }_{3}{ }^{2+}$, linked by $1,4-$ phenylene units $(n=2,3,4$, or 5$)$. Furthermore, the

(35) Osawa, M.; Hoshino, M.; Horiushi, S.; Wakatsuki, Y. Organometallics 1999, $18,112-114$.

(36) Fernandez-Acebes, A.; Lehn, J. M. Chem.-Eur. J. 1999, 5, 32853292.

(37) Fraysse, S.; Coudret, C.; Launay, J. P. Eur. J. Inorg. Chem. 2000, $1581-1590$.

(38) Jukes, R. T. F.; Adamo, V.; Hartl, F.; Belser, P.; De Cola, L. Inorg. Chem. 2004, 43, 2779-2792.

(39) Weldon, F.; Hammarstrom, L.; Mukhtar, E.; Hage, R.; Gunneweg, E.; Haasnoot, J. G.; Reedijk, J.; Browne, W. R.; Guckian, A. L.; Vos, J. G. Inorg. Chem. 2004, 43, 4471-4481.

(40) Welter, S.; Salluce, N.; Belser, P.; Groenefeld, M.; De Cola, L. Coord. Chem. Rev., in press.

(41) Baba, A. I.; Wang, W.; Kim, W. Y.; Strong, L.; Schmehl, R. H. Synth. Commun. 1994, 24, 1029-1036.

(42) Constable, E. C.; Thompson, A. New J. Chem. 1996, 20, 65-82.

(43) Barron, J. A.; Glazier, S.; Bernhard, S.; Takada, K.; Houston, P. L.; Abruna, H. D. Inorg. Chem. 2003, 42, 1448-1455.

(44) Aspley, C. J.; Williams, J. A. G. New J. Chem. 2001, 25, 11361147.

(45) Hammarstrom, L.; Barigelletti, F.; Flamigni, L.; Indelli, M. T.; Armaroli, N.; Calogero, G.; Guardigli, M.; Sour, A.; Collin, J.-P.; Sauvage, J.-P. J. Phys. Chem. A 1997, 101, 9061-9069.

(46) Barigelletti, F.; Flamigni, L.; Guardigli, M.; Sauvage, J.-P.; Collin, J.-P.; Sour, A. Chem. Commun. 1996, 1329-1330.

(47) Collin, J.-P.; Laine, P.; Launay, J.-P.; Sauvage, J.-P.; Sour, A. J. Chem. Soc., Chem. Commun. 1993, 434-435.

(48) Indelli, M. T.; Scandola, F.; Flamigni, L.; Collin, J.-P.; Sauvage, J.-P.; Sour, A. Inorg. Chem. 1997, 36, 4247-4250.

(49) Indelli, M. T.; Scandola, F.; Collin, J.-P.; Sauvage, J.-P.; Sour, A. Inorg. Chem. 1996, 35, 303-312.

(50) Barigelletti, F.; Flamigni, L.; Collin, J.-P.; Sauvage, J.-P. Chem. Сотmun. 1997, 333-338.

(51) Barigelletti, F.; Flamigni, L.; Balzani, V.; Collin, J.-P.; Sauvage, J.P.; Sour, A.; Constable, E. C.; Thompson, A. Coord. Chem. Rev. 1994, 132, 209-214.

(52) Barigelletti, F.; Flamigni, L.; Balzani, V.; Collin, J.-P.; Sauvage, J.-P.; Sour, A.; Constable, E. C.; Thompson, A. M. W. C. J. Am. Chem Soc. 1994, 116, 7692-7699.

(53) Constable, E. C.; Thompson, A. M. W. C.; Tocher, D. A. Polym. Prepr. (Am. Chem. Soc., Div. Polym. Chem.) 1993, 34, 110-111.

(54) Barigelletti, F.; Flamigni, L.; Balzani, V.; Collin, J.-P.; Sauvage, J.-P.; Sour, A.; Constable, E. C.; Thompson, A. J. Chem. Soc., Chem. Commun. 1993, 942-944.

(55) Collin, J.-P.; Gavina, P.; Heitz, V.; Sauvage, J.-P. Eur. J. Inorg. Chem. 1998, $1-14$

(56) Constable, E. C.; Thompson, A.; Tocher, D. A. Macromol. Symp. 1994, 77, 219-228.

(57) Kelch, S.; Rehahn, M. Macromolecules 1999, 32, 5818-5828.

(58) Schlicke, B.; Belser, P.; De Cola, L.; Sabbioni, E.; Balzani, V. J. Am. Chem. Soc. 1999, 121, 4207-4214.

(59) Plummer, E. A.; Hofstraat, J. W.; De Cola, L. Dalton Trans. 2003, $2080-2084$ 
Welter et al.

Chart 1. Schematic Formula, Abbreviations, and Metal-to-Metal Distances of the Investigated Compounds

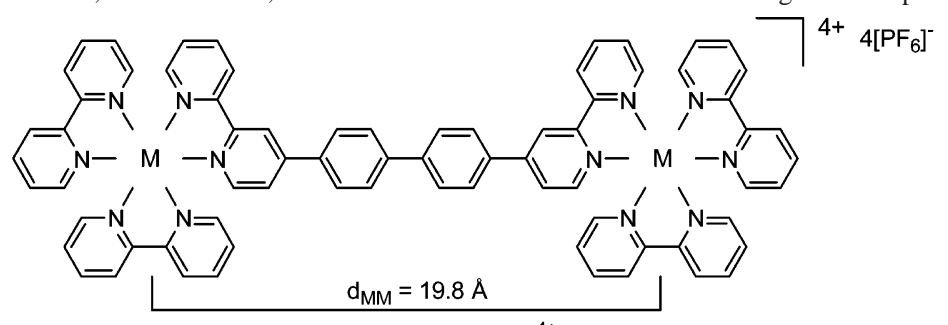

$1 \mathrm{M}=\mathrm{Ru}=\left[\mathrm{Ru}-\mathrm{ph}_{2}-\mathrm{Ru}\right]^{4+}$

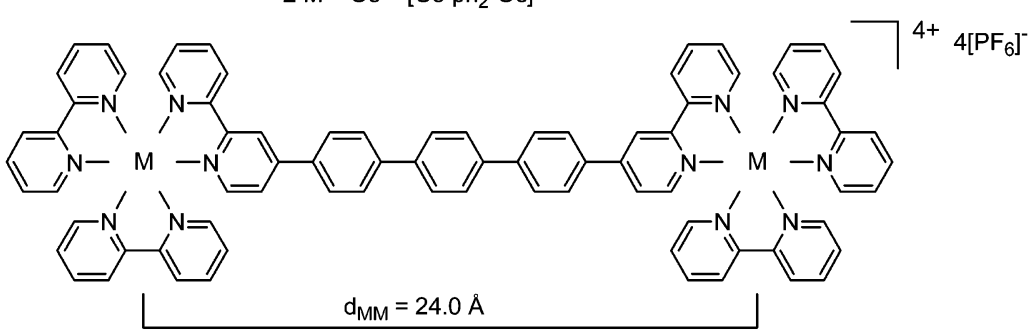

$3 \mathrm{M}=\mathrm{Ru}=\left[\mathrm{Ru}-\mathrm{ph}_{3}-\mathrm{Ru}\right]^{4+}$

$4 \mathrm{M}=\mathrm{Os}=\left[\mathrm{Os}-\mathrm{ph}_{3}-\mathrm{Os}\right]^{4+}$

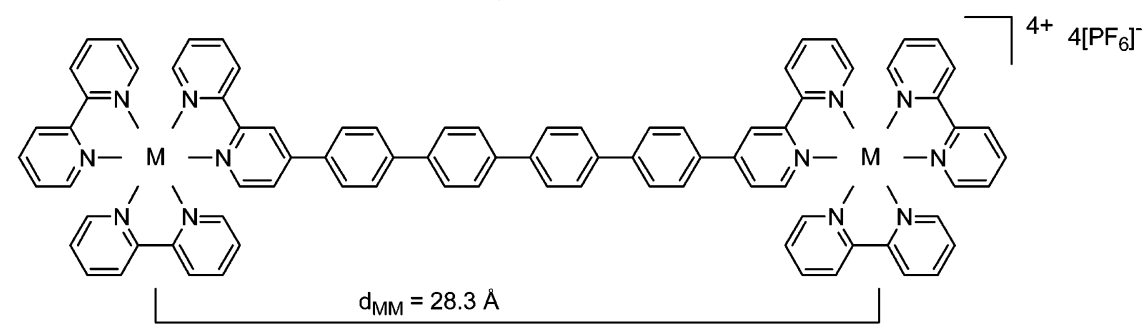

$5 \mathrm{M}=\mathrm{Ru}=\left[\mathrm{Ru}-\mathrm{ph}_{4}-\mathrm{Ru}\right]^{4+}$

$6 \mathrm{M}=\mathrm{Os}=\left[\mathrm{Os}-\mathrm{ph}_{4}-\mathrm{Os}\right]^{4+}$

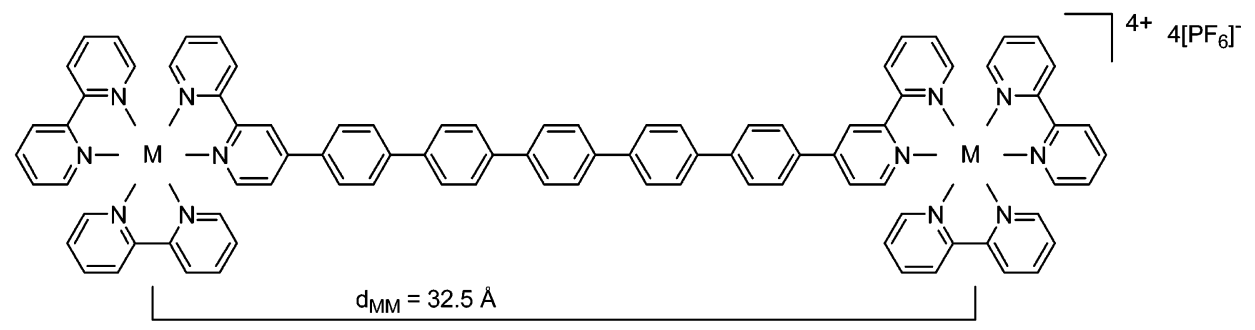

$\mathrm{M}=\mathrm{Ru}=\left[\mathrm{Ru}-\mathrm{ph}_{5}-\mathrm{Ru}\right]^{4+}$

$8 \mathrm{M}=\mathrm{Os}=\left[\mathrm{Os}-\mathrm{ph}_{5}-\mathrm{Os}\right]^{4+}$
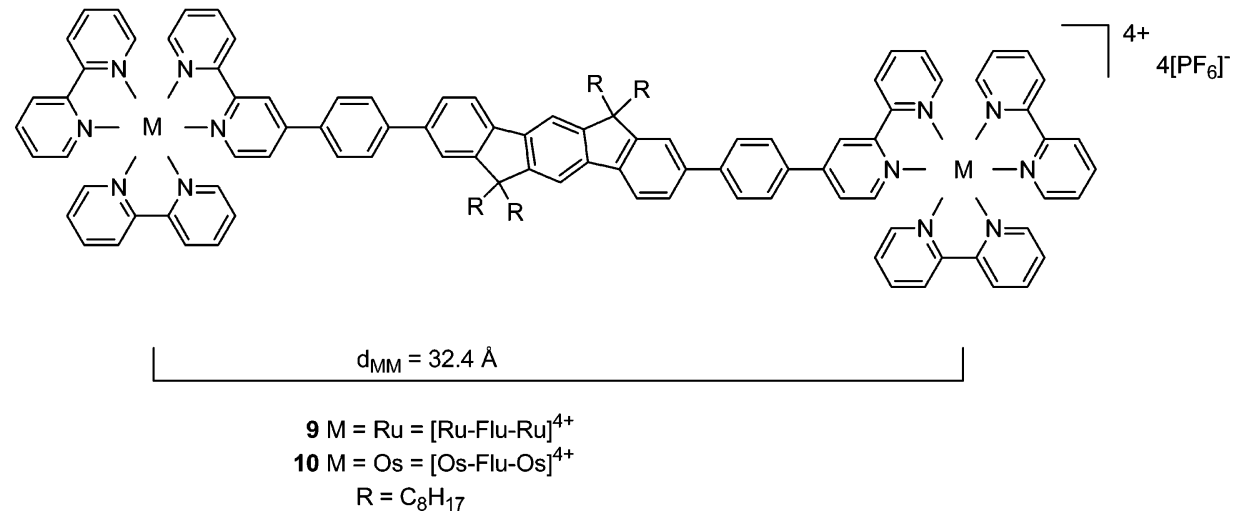

homometallic complexes containing an indenofluorene spacer that force the phenyl rings in a coplanar geometry are also reported. In particular, the synthetic strategy to prepare the unsubstituted phenyl complexes using the "chemistry on the complex" approach, ${ }^{60-62}$ the electrochemical and photophysi-

cal properties of all the compounds, and the crystal structure of one of the ruthenium complexes are reported. The possibility of varying the tilt angle between adjacent phenyls opens new perspectives in the modulation of the electronic interactions between the terminal units.

4708 Inorganic Chemistry, Vol. 44, No. 13, 2005 
Scheme 1. Synthetic Scheme for the Dinuclear Ruthenium Complexes Containing Two, Three, Four, and Five Phenyls as Bridging Ligand ${ }^{a}$

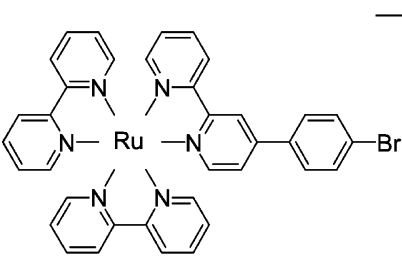

18 [Rubpy-ph-Br] ${ }^{2+}$
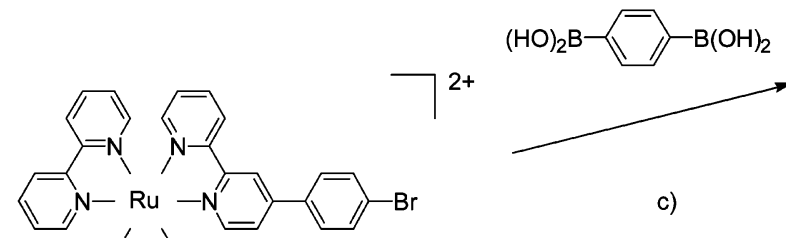

(N)

$18[\text { Rubpy-ph-Br] }]^{2+}$

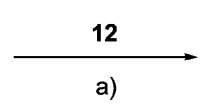

a)

$T^{2+}$

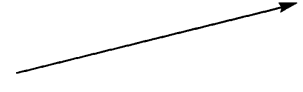

c)

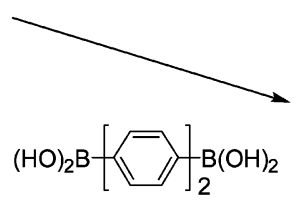

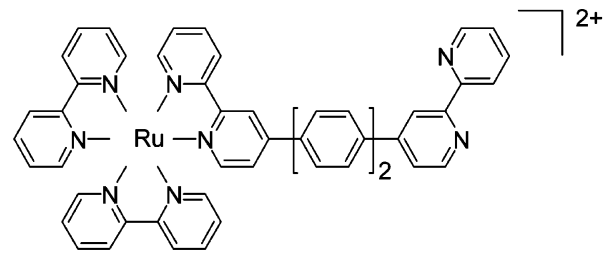

19 [Rubpy-ph ${ }_{2}-$ bpy $]^{2+}$

b)
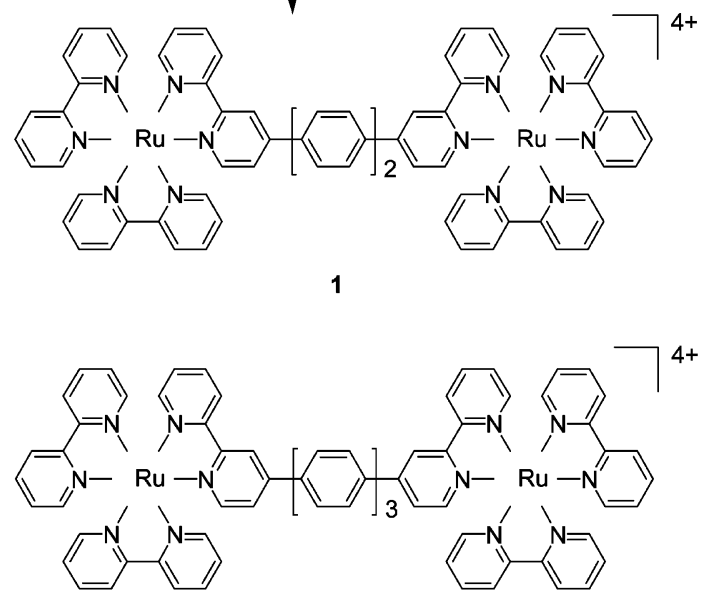

3

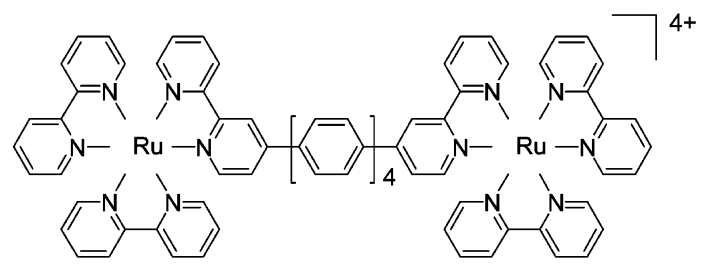

5

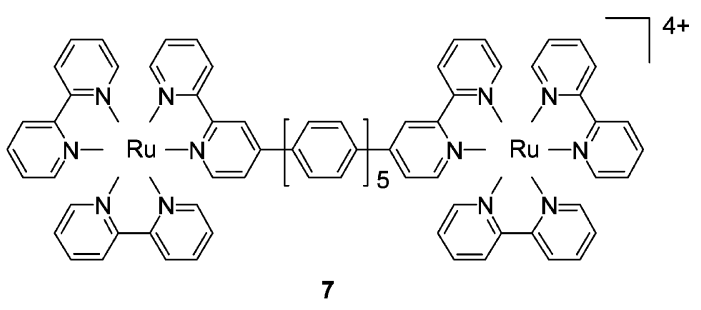

$20\left[\text { Rubpy-ph }{ }_{2}-1\right]^{2+}$
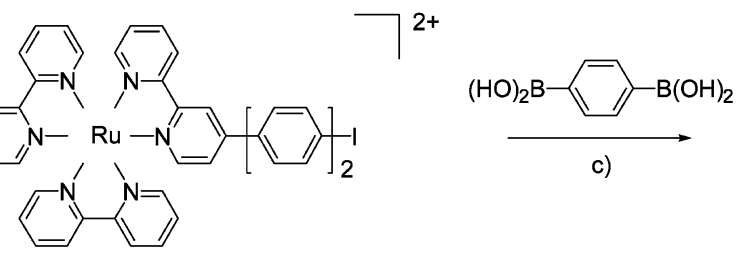

c)

${ }^{a}$ (a) $\mathrm{K}_{2} \mathrm{CO}_{3}, \mathrm{DMF}, 120{ }^{\circ} \mathrm{C}, 24 \mathrm{~h}, 74 \%$; (b) $\mathrm{Ru}$ (bpy) ${ }_{2} \mathrm{Cl}_{2}$, ethylene glycol, microwave irradiation ( $450 \mathrm{~W}, 3 \times 2 \mathrm{~min}$.), $78 \%$; (c) $\left.\mathrm{K}_{2} \mathrm{CO}_{3}, \mathrm{Pd}_{(\mathrm{PPh}}\right)_{4}, \mathrm{DMF}$, $95^{\circ} \mathrm{C}, 16 \mathrm{~h}, 77-80 \%$.

\section{Results and Discussion}

All the complexes synthesized and investigated, including their abbreviations, are shown in Chart 1 . They have been isolated and used as $\mathrm{PF}_{6}{ }^{-}$salts. For comparison purposes, the $\mathrm{M}(\mathrm{bpy}) 3^{2+}(\mathrm{M}=\mathrm{Ru}$ or $\mathrm{Os})$ and/or the mononuclear compounds containing two phenylene units, [Mbpy- $\mathrm{ph}_{2^{-}}$ bpy $]^{2+}$, have been employed.

(60) Baranoff, E.; Dixon, I. M.; Collin, J.-P.; Sauvage, J.-P.; Ventura, B.; Flamigni, L. Inorg. Chem. 2004, 43, 3057-3066.

(61) Tzalis, D.; Tor, Y. J. Am. Chem. Soc. 1997, 119, 852-853.

(62) Chodorowski-Kimmes, S.; Beley, M.; Collin, J.-P.; Sauvage, J.-P. Tetrahedron Lett. 1996, 37, 2963-2966.
Synthesis. As a result of the low solubility and difficult preparation of "bare" polyphenylene-substituted 2,2'-bipyridines, bpy, the general procedure based on the complexation of $\left[\mathrm{Ru}(\mathrm{bpy})_{2} \mathrm{Cl}_{2}\right]$ with the chelating substituted bpy was not employed. Instead, we used the "chemistry on the metal" approach where the charged metal complex helps to solubilize the polyphenylene chain and hence allows a stepwise construction of the bridge with Suzuki cross-coupling reactions. ${ }^{63}$ The starting compound for all the ruthenium complexes is a derivative of ruthenium tris-bipyridine, [Rubpyph-Br $]^{2+}[\mathbf{1 8}]$, containing two unsubstituted and one

(63) Miyaura, N.; Suzuki, A. Chem. Rev. 1995, 95, 2457-2483. 
Welter et al.

Scheme 2. Synthesis of $[\mathrm{Ru}-\mathrm{Flu}-\mathrm{Ru}]\left(\mathrm{PF}_{6}\right)_{4}$ and $[\mathrm{Os}-\mathrm{Flu}-\mathrm{Os}]\left(\mathrm{PF}_{6}\right)_{4}{ }^{a}$
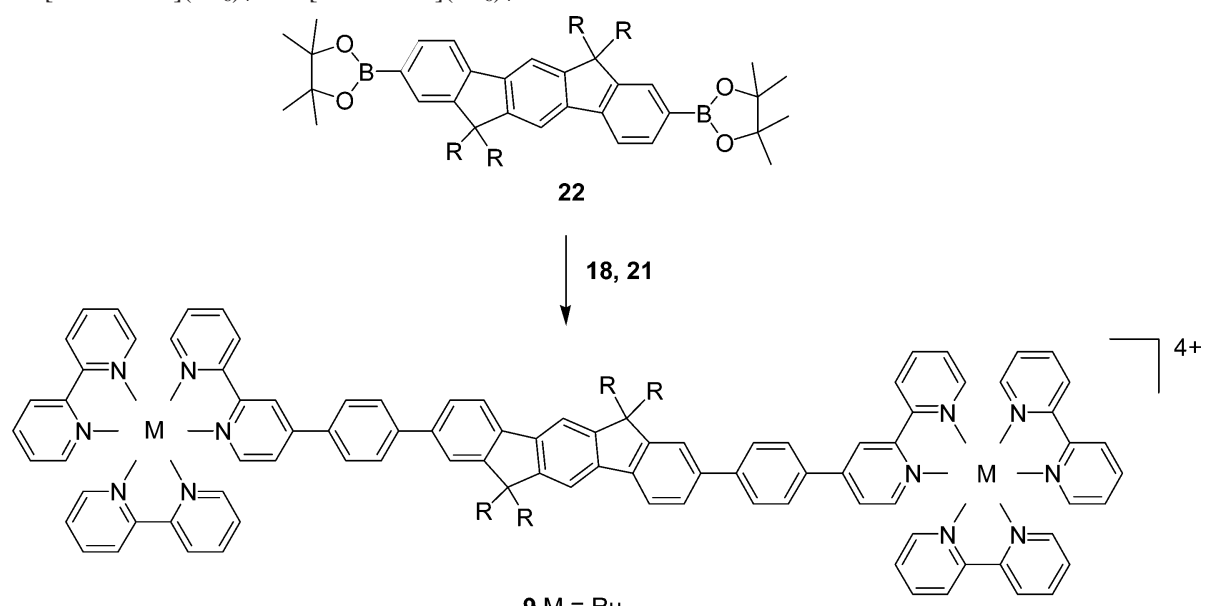

$\begin{aligned} 9 \mathrm{M} & =\mathrm{Ru} \\ 10 \mathrm{M} & =\mathrm{Os}\end{aligned}$

$\mathrm{R}=\mathrm{C}_{8} \mathrm{H}_{17}$

${ }^{a} \mathrm{Na}_{2} \mathrm{CO}_{3}, \mathrm{Pd}\left(\mathrm{PPh}_{3}\right)_{4}, \mathrm{DMF}, 90{ }^{\circ} \mathrm{C}, 16 \mathrm{~h}$.

functionalized 4-(4'-bromophenyl)-[2,2']bipyridinyl ligand ${ }^{64}$ (Scheme 1). The cross-coupling reaction with 1,4-benzenediboronic acid and 4,4'-biphenyldiboronic acid, using $\operatorname{Pd}(0)$ as catalyst, readily yields the bimetallic ruthenium complexes connected by three and four phenylene units, respectively (Scheme 1). The same approach was also used for the $[\mathrm{Ru}-$ Flu-Ru $]^{4+}$ complex containing an indenofluorene type of bridging ligand. For the latter complex the indenofluorene derivative [22] with two boronic acids was used in a Suzukitype cross-coupling reaction to give the bimetallic complex in good yield (Scheme 2). For the longest bimetallic complex with five phenylene units [7], we previously synthesized the monometallic ruthenium complex with two phenylene units by coupling [Rubpy-ph-Br] ${ }^{2+}$ with 4-trimethylsilylphenylboronic acid followed by deprotection of the trimethysilyl group with iodine chloride (ICl). This halogen-functionalized ruthenium complex can further undergo a cross-coupling reaction with 1,4-benzenediboronic acid to obtain the bimetallic ruthenium complex with five phenyl units (Scheme 1). For the shortest complex with two phenylene units, a different approach was used: [Rubpy-ph-Br] ${ }^{2+}$ was crosscoupled with bpy-ph-B $(\mathrm{OR})_{2}[\mathbf{1 2}]$ bearing a boronic ester to give the monometallic complex with the biphenylene spacer [19] and a free complexing site where the second ruthenium or other metal complexes can be coordinated. ${ }^{40}$

The synthetic approach described for the bimetallic ruthenium complexes could not be readily adopted for the corresponding osmium complexes. In fact, the coupling of two [Osbpy-ph-Br] ${ }^{2+}$ units with bisboronic acids of monoand biphenyl, using $\operatorname{Pd}(0)$ as catalyst, only gave poor yields for the bimetallic complexes in most cases. Only in the case of [Os-Flu-Os] $]^{4+}$ and $\left[\mathrm{Os}-\mathrm{ph}_{3}-\mathrm{Os}\right]^{4+}$ was this approach used (Schemes 2 and 4). In fact, in most of the cases an undesired side-product was obtained as the final osmium complex when reacting [Osbpy-ph-Br] ${ }^{2+}$ in a 2:1 stoichiometry with a monoor biphenyl unit, containing two boronic acids and using Pd-

(64) Bossart, O.; De Cola, L.; Welter, S.; Calzaferri, G. Chem.-Eur. J. 2004, 10, 5771-5775.
$\left(\mathrm{PPh}_{3}\right)_{4}$ as catalyst in DMF. On the basis of mass spectroscopy results, we tentatively assigned the structure to an osmium complex containing a diphenylphosphine (originating from the catalyst, $\left.\mathrm{Pd}\left(\mathrm{PPh}_{3}\right)_{4}\right)$ linked to the phenylene. However, under the same reaction conditions, [Osbpy-ph$\mathrm{Br}]^{2+}$ has coupled with an excess of 4-trimethylsilylphenylboronic acid in high yield ( $90 \%)$. To avoid the previously described problems, we opted for a more classical approach to obtain the bimetallic osmium complexes. Indeed, most homometallic dinuclear complexes reported in the literature are obtained by complexing two osmium units to the finished bridging ligand that contains two free coordinating sites. The free bis-bipyridine bridging ligands with two, four, and five phenylenes were synthesized according to the procedure sketched in Scheme 3. The longer ligands were almost insoluble and were further used without purification. The bimetallic osmium complexes were obtained by microwave irradiation of a mixture of the ligand and $\left[\mathrm{Os}(\mathrm{bpy})_{2} \mathrm{Cl}_{2}\right]$ in ethylene glycol (Scheme 4). Only relatively low yields of $20-24 \%$ were obtained for the complexes with four and five phenylene units, probably as a result of the low solubility of the ligand. Indeed, for the shortest ligand with two phenylene units, a much higher yield of $84 \%$ was obtained.

It is therefore interesting to notice that the "chemistry on the complex" approach is very effective in the case of the bimetallic ruthenium complexes. However, this method is not suitable for the synthesis of dinuclear osmium complexes and yields large amounts of undesired side-products. So far we have no explanation for the different chemical behavior of Ru and Os. All the details on the synthesis and the full characterization of the complexes are reported in the Experimental Section.

Photophysical Properties. The absorption spectra of the dinuclear complexes as well as the complexes containing the indenofluorene bridging ligand are shown in Figures 1 and 2 for the ruthenium and osmium series, respectively. Also, the spectra of the reference compounds $\mathrm{M}(\mathrm{bpy})_{3}{ }^{2+}$ (M $=\mathrm{Ru}$ or Os) are shown for comparison. The spectra of both 
Scheme 3. Synthetic Protocol for the Preparation of the Bridging Ligands ${ }^{a}$

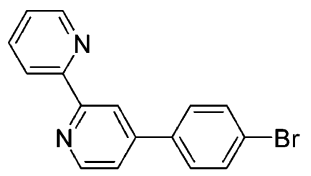

11 bpy-ph-Br

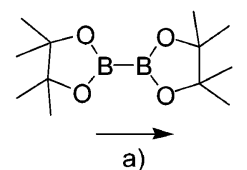

a)

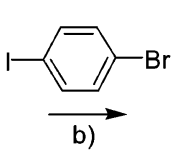

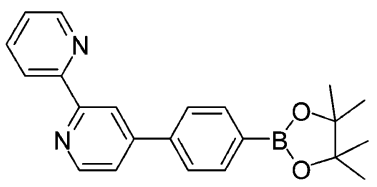

12 bpy-ph-B $(\mathrm{OR})_{2}$

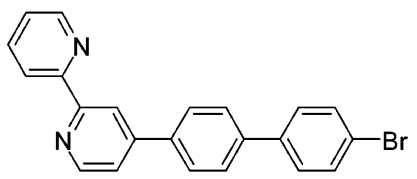

13 bpy-ph $-\mathrm{Br}$

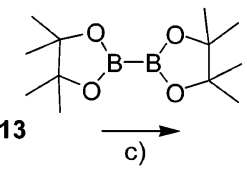

$\stackrel{\text { d) }}{\longrightarrow}$

$13+14 \underset{\mathrm{e})}{\longrightarrow}$

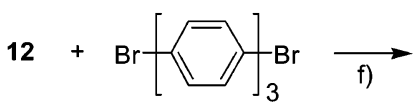

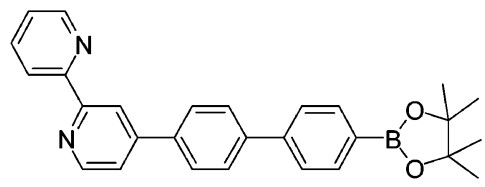

14 bpy-ph $2-B(O R)_{2}$
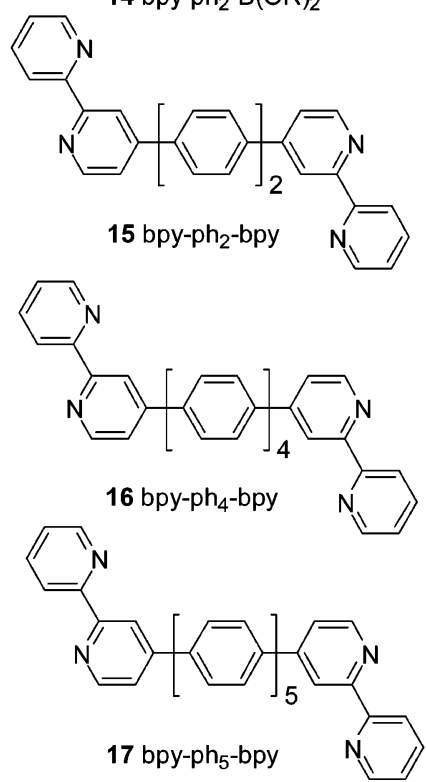

a (a) AcOK, DMSO, $\mathrm{PdCl}_{2}$ (dppf), $105^{\circ} \mathrm{C}, 17 \mathrm{~h}, 85 \%$; (b) $\mathrm{Na}_{2} \mathrm{CO}_{3}$, toluene, $\mathrm{Pd}\left(\mathrm{PPh}_{3}\right)_{4}, 95^{\circ} \mathrm{C}, 48 \mathrm{~h}, 70 \%$; (c) $\mathrm{AcOK}, \mathrm{DMSO}, \mathrm{PdCl} 2$ (dppf), $105{ }^{\circ} \mathrm{C}, 25 \mathrm{~h}$, 94\%; (d) $\mathrm{K}_{2} \mathrm{CO}_{3}, \mathrm{DMF}, \mathrm{Pd}\left(\mathrm{PPh}_{3}\right)_{4}, 120^{\circ} \mathrm{C}, 20 \mathrm{~h}, 55 \%$; (e) $\mathrm{Na}_{2} \mathrm{CO}_{3}$, toluene, $\mathrm{Pd}\left(\mathrm{PPh}_{3}\right)_{4}, 95{ }^{\circ} \mathrm{C}, 50 \mathrm{~h}, 87 \%$; (f) $\mathrm{Na}_{2} \mathrm{CO}_{3}$, toluene, $\mathrm{Pd}\left(\mathrm{PPh}_{3}\right)_{4}, 95{ }^{\circ} \mathrm{C}, 48 \mathrm{~h}, 80 \%$.

series recorded in air-equilibrated acetonitrile show the typical features of the reference complexes with additional bands corresponding to the bridging ligand. In the UV region, the band at $290 \mathrm{~nm}$ is assigned to a singlet intraligand ( $\left.{ }^{1} \mathrm{IL}\right)$ $\pi-\pi^{*}$ transition of the three bipyridine units. The region 300-350 nm shows the absorbance of the oligophenylene spacers $\left({ }^{1} \mathrm{IL}, \pi-\pi^{*}\right)$. With an increase in the number of phenylene units, the conjugation length increases and results in a red-shift for the maxima $(320-350 \mathrm{~nm})$, corresponding to a lowering of the LUMO orbital, and therefore of the HOMO-LUMO gap, and a simultaneous increase of the molar extinction coefficient. In the case of $[\mathrm{M}-\mathrm{Flu}-\mathrm{M}]^{4+}(\mathrm{M}$ $=\mathrm{Ru}$, Os) complexes, a remarkable red-shift of the phenylene band is observed due to the forced planarization of the phenylene units resulting in a larger $\pi$-conjugation between the aromatic moieties. The influence of the planarization of the phenylene units in the indenofluorene bridging ligand can be easily seen by comparing the $\pi-\pi^{*}$ transition bands in the $[\mathrm{M}-\mathrm{Flu}-\mathrm{M}]^{4+}$ and the $\left[\mathrm{M}-\mathrm{ph}_{5}-\mathrm{M}\right]^{4+}$ complexes. In fact, for the ground state, the tilt angle in the phenylene compounds is $23^{\circ}$ while it is $0^{\circ}$ for the indenofluorene units. This effect results in a strong red-shift (3690 and $3080 \mathrm{~cm}^{-1}$ for the corresponding ruthenium and osmium complexes, respectively) of the band attributed to phenylene units of the indenofluorene in the $[\mathrm{M}-\mathrm{Flu}-\mathrm{M}]^{4+}$ compared with the phenylene moieties for the $\left[\mathrm{M}-\mathrm{ph}_{5}-\mathrm{M}\right]^{4+}$ complexes (Figures 1 and 2).

In the visible region, the comparison between the monometallic complex [Rubpy-ph-Br] ${ }^{2+}$ and the bimetallic complex $\left[\mathrm{Ru}-\mathrm{ph}_{2}-\mathrm{Ru}\right]^{4+}$ shows no appreciable red-shift of the absorption bands, indicating that the electronic coupling between the two terminal metal units is very small. The lowest energy absorption, at about $460 \mathrm{~nm}$, is attributed to singlet metal-to-ligand charge transfer ( $\left.{ }^{1} \mathrm{MLCT}\right)$ transitions involving both the bipyridine on the bridging ligands (BL), $\mathrm{M}(\mathrm{d} \pi) \rightarrow \mathrm{BL}\left(\pi^{*}\right)$ and the ancillary bpy's $\mathrm{M}(\mathrm{d} \pi) \rightarrow$ bpy$\left(\pi^{*}\right)$. In fact, all the chelating ligands are expected to have very similar energies, as can also be seen from the electro- 
Welter et al.

Scheme 4. Synthesis of $\left[\mathrm{Os}-\mathrm{ph}_{n}-\mathrm{Os}\right]\left(\mathrm{PF}_{6}\right)_{4}$ Complexes $(n=2,3,4$, $5)^{a}$
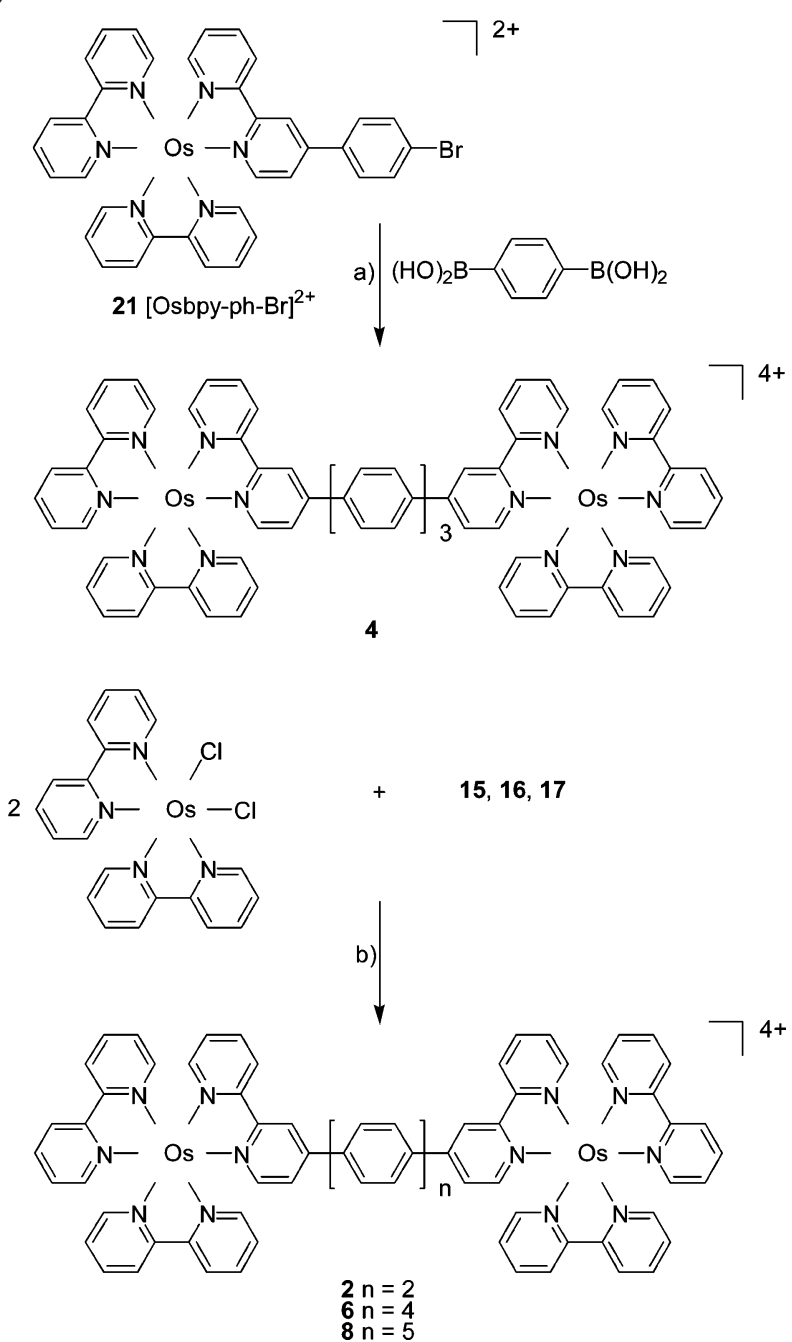

a (a) $\mathrm{K}_{3} \mathrm{PO}_{4}, \mathrm{Pd}\left(\mathrm{PPh}_{3}\right)_{4}$, ethanol, dioxane, $95^{\circ} \mathrm{C}, 16 \mathrm{~h}, 70 \%$; (b) ethylene glycol, microwave irradiation $(450 \mathrm{~W}, 3 \times 2 \mathrm{~min})$.

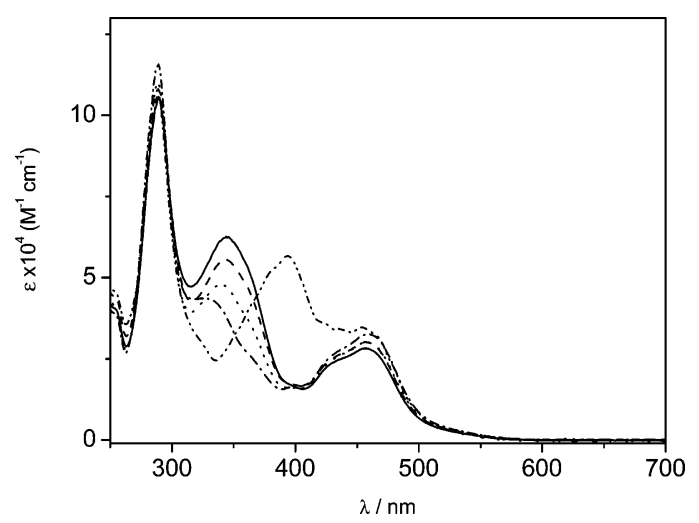

Figure 1. Absorption spectra of the homometallic ruthenium complexes in acetonitrile, $\left[\mathrm{Ru}-\mathrm{ph}_{2}-\mathrm{Ru}\right]^{4+}(-\cdot-),\left[\mathrm{Ru}-\mathrm{ph}_{3}-\mathrm{Ru}\right]^{4+}(\cdots),\left[\mathrm{Ru}-\mathrm{ph}_{4}-\mathrm{Ru}\right]^{4+}$ $(--),\left[R u-p_{5}-\mathrm{Ru}\right]^{4+}(-)$, and $[\mathrm{Ru}-\mathrm{Flu}-\mathrm{Ru}]^{4+}(-\cdot-)$. With increasing numbers of phenyl rings, the maxima at $325 \mathrm{~nm}$ are shifted to the red and increase in intensity.

chemical investigations (vide infra). The MLCT absorption bands of the $\left[\mathrm{Os}-\mathrm{ph}_{n}-\mathrm{Os}\right]^{4+}$ complexes are red-shifted compared to the analogous ruthenium complexes because of the higher energy of the HOMO orbital as a result of the presence of the heavier atom. Additionally, the osmium

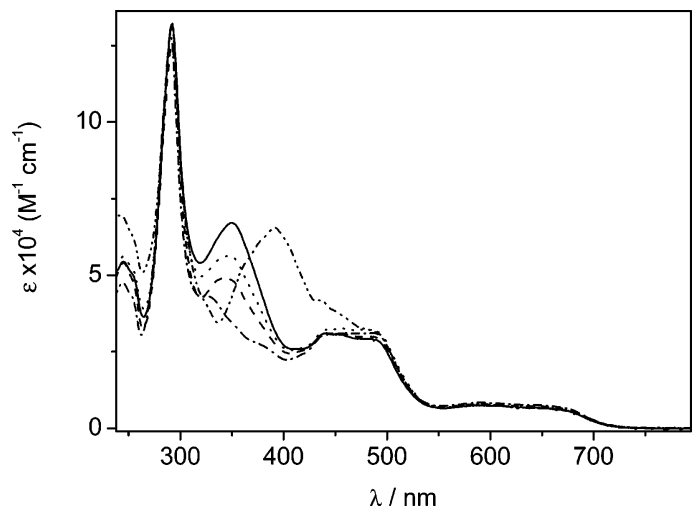

Figure 2. Absorption spectra of the homometallic osmium complexes in acetonitrile, $\left[\mathrm{Os}-\mathrm{ph}_{2}-\mathrm{Os}\right]^{4+}(-\cdot-),\left[\mathrm{Os}-\mathrm{ph}_{3}-\mathrm{Os}\right]^{4+}(---),\left[\mathrm{Os}-\mathrm{ph}_{4}-\mathrm{Os}\right]^{4+}$ $(\cdots),\left[\mathrm{Os}-\mathrm{ph}_{5}-\mathrm{Os}\right]^{4+}(-)$, and $[\mathrm{Os}-\mathrm{Flu}-\mathrm{Os}]^{4+}(-\cdots-)$.

Table 1. Photophysical Properties of Dinuclear Ruthenium Complexes Bridged by Oligophenylene Spacers

\begin{tabular}{|c|c|c|c|c|c|c|c|}
\hline \multirow[b]{3}{*}{$\lambda, \mathrm{nm}$} & \multirow{3}{*}{$\frac{\text { abs. }^{a}}{\lambda, \mathrm{nm}}$} & \multicolumn{6}{|c|}{ luminescence } \\
\hline & & \multicolumn{4}{|c|}{$298 \mathrm{~K}^{a}$} & \multicolumn{2}{|c|}{$77 \mathrm{~K}^{b}$} \\
\hline & & $\lambda, \mathrm{nm}$ & $\tau, \mathrm{ns}$ & $\tau, \mu \mathrm{s}^{c}$ & $\varphi_{\mathrm{em}}$ & $\lambda, \mathrm{nm}$ & $\tau, \mu \mathrm{s}$ \\
\hline$[\text { Rubpy-ph } 2 \text {-bpy }]^{2+}$ & 456 & 626 & 207 & 1.7 & 0.079 & 590 & 6.4 \\
\hline$\left[\mathrm{Ru}-\mathrm{ph}_{2}-\mathrm{Ru}\right]^{4+}$ & 457 & 625 & 213 & 1.9 & 0.075 & 595 & 6.4 \\
\hline$\left[\mathrm{Ru}-\mathrm{ph}_{3}-\mathrm{Ru}\right]^{4+}$ & 457 & 625 & 198 & 1.7 & 0.073 & 596 & 6.1 \\
\hline$\left[\mathrm{Ru}-\mathrm{ph}_{4}-\mathrm{Ru}\right]^{4+}$ & 457 & 625 & 206 & 1.7 & 0.071 & 595 & 6.4 \\
\hline$\left[\mathrm{Ru}-\mathrm{ph}_{5}-\mathrm{Ru}\right]^{4+}$ & 457 & 625 & 210 & 1.7 & 0.070 & 595 & 6.1 \\
\hline$[\text { Ru-Flu-Ru }]^{4+}$ & 466 & 624 & 195 & 1.7 & 0.084 & 594 & 6.1 \\
\hline$\left[\mathrm{Ru}(\mathrm{bpy})_{3}\right]^{2+}$ & 451 & 616 & 160 & 0.89 & $0.062^{d}$ & 579 & 4.8 \\
\hline
\end{tabular}

${ }^{a}$ Air-equilibrated acetonitrile $\left(\lambda_{\mathrm{exc}}=435 \mathrm{~nm}\right) .{ }^{b}$ Butyronitrile solid matrix. ${ }^{c}$ Deaerated acetonitrile solution. ${ }^{d}$ Ref 73 .

Table 2. Photophysical Properties of Dinuclear Osmium Complexes Bridged by Oligophenylene Spacers

\begin{tabular}{|c|c|c|c|c|c|c|c|}
\hline & \multirow{3}{*}{$\frac{\text { abs. }^{a}}{\lambda, \mathrm{nm}}$} & \multicolumn{6}{|c|}{ luminescence } \\
\hline & & \multicolumn{4}{|c|}{$298 \mathrm{~K}^{a}$} & \multicolumn{2}{|c|}{$77 \mathrm{~K}^{b}$} \\
\hline & & $\lambda, \mathrm{nm}$ & $\tau, \mathrm{ns}$ & $\tau, \mathrm{ns}^{c}$ & $\varphi_{\mathrm{em}} 10^{-3}$ & $\lambda, \mathrm{nm}$ & $\tau, \mu \mathrm{s}$ \\
\hline$[\text { Os-ph } 2-\mathrm{Os}]^{4+}$ & 592 & 751 & 44 & 64 & 4.2 & 722 & 1.1 \\
\hline$\left[\mathrm{Os}-\mathrm{ph}_{3}-\mathrm{Os}\right]^{4+}$ & 593 & 744 & 42 & 63 & 4.1 & 720 & 1.1 \\
\hline$\left[\mathrm{Os}-\mathrm{ph}_{4}-\mathrm{Os}\right]^{4+}$ & 593 & 746 & 44 & 62 & 4.3 & 719 & 1.0 \\
\hline$\left[\mathrm{Os}-\mathrm{ph}_{5}-\mathrm{Os}\right]^{4+}$ & 591 & 746 & 42 & 62 & 4.6 & 719 & 1.0 \\
\hline$\left[\right.$ Os-Flu-Os] ${ }^{4+}$ & 592 & 748 & 42 & 64 & 4.7 & 720 & 1.0 \\
\hline$\left[\mathrm{Os}(\mathrm{bpy})_{3}\right]^{2+}$ & 583 & 743 & 40 & 60 & $3.5^{d}$ & 710 & 0.83 \\
\hline
\end{tabular}

${ }^{a}$ Air-equilibrated acetonitrile $\left(\lambda_{\text {exc }}=435 \mathrm{~nm}\right) .{ }^{b}$ Butyronitrile solid matrix. ${ }^{c}$ Deaerated acetonitrile solution. ${ }^{d}$ Ref 65.

complexes show a weak absorption band $(560-670 \mathrm{~nm})$ that is assigned to spin-forbidden electronic transitions $\left({ }^{3} \mathrm{MLCT}\right)$, partly allowed due to strong spin-orbit coupling in the osmium complexes. ${ }^{65}$

The emission spectra of all the metal complexes were recorded in acetonitrile at room temperature and in butyronitrile glass at $77 \mathrm{~K}$ upon excitation at $435 \mathrm{~nm}$. The spectroscopic data are summarized in Tables 1 and 2 for the ruthenium and osmium series, respectively. The roomtemperature luminescence spectra for the complexes containing the longest phenylene spacer, $\left[\mathrm{Ru}-\mathrm{ph}_{5}-\mathrm{Ru}\right]^{4+}$, the indenofluorene spacer, $[\mathrm{Ru}-\mathrm{Flu}-\mathrm{Ru}]^{4+}$, and the reference compound $\left[\mathrm{Ru}(\mathrm{bpy})_{3}\right]^{2+}$ are shown in Figure 3. All the ruthenium bimetallic complexes show the same maximum $(625 \mathrm{~nm})$

(65) Kober, E. M.; Caspar, J. V.; Lumpkin, R. S.; Meyer, T. J. J. Phys. Chem. 1986, 90, 3722-3734. 


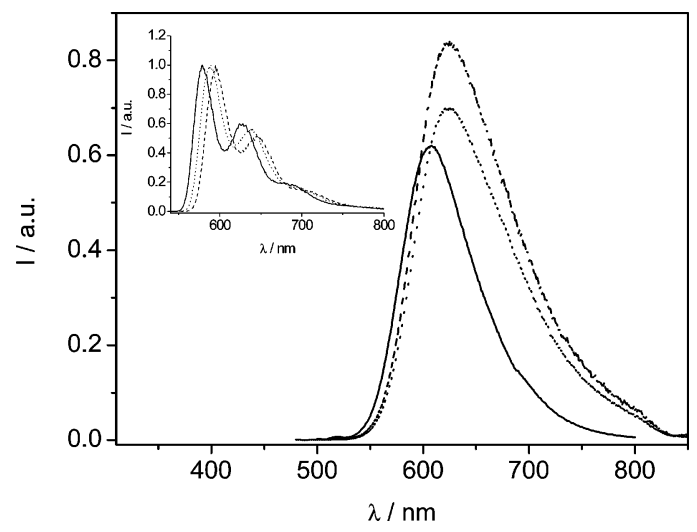

Figure 3. Luminescence spectra of the complexes $\left[\mathrm{Rubpy}_{3}\right]^{2+}(-),[\mathrm{Ru}-$ $\left.\mathrm{ph}_{5}-\mathrm{Ru}\right]^{4+}(\cdots)$, and $[\mathrm{Ru}-\mathrm{Flu}-\mathrm{Ru}]^{4+}(---)$ in acetonitrile solution at $293 \mathrm{~K}$ $\left(\lambda_{\text {exc }}=435 \mathrm{~nm}\right)$. The inset shows the emission spectra at $77 \mathrm{~K}$ in butyronitrile rigid matrix of $\left[\operatorname{Rubpy}_{3}\right]^{2+}(-)$, [Rubpy-ph-Br $]^{2+}(\cdots)$, and $\left[\mathrm{Ru}-\mathrm{ph}_{2}-\mathrm{Ru}\right]^{4+}(---)$

and band-shape for the emission. Compared to $\left[\mathrm{Ru}(\mathrm{bpy})_{3}\right]^{2+}$, we observe a small red-shift for all the bimetallic complexes of about $10 \mathrm{~nm}$, indicating a lowering in energy of the emissive ${ }^{3}$ MLCT state. The same red-shift of $10 \mathrm{~nm}$ is also observed for the mononuclear [Rubpy-ph $\mathrm{p}_{2}$-bpy] ${ }^{2+}$ complex, clearly indicating that the shift in emission is not due to the second metal center. This result already suggests that the LUMO of the substituted bipyridine is lower in energy than those of the ancillary bipyridines. This observation is in accordance with the reduction potentials obtained for the bimetallic complexes and with the transient absorption spectra (vide infra). The excited-state lifetimes and quantum yields of the bimetallic complexes at room temperature in aerated conditions are higher than for $\left[\mathrm{Ru}(\mathrm{bpy})_{3}\right]^{2+}$, whereas in deaerated conditions the lifetime for the bimetallic complexes is almost double that for $\left[\mathrm{Ru}(\mathrm{bpy})_{3}\right]^{2+}$. The emission quantum yields mirror these results (see Table 1), indicating that the polyphenylene units appended to the bipyridine play a major role in the delocalization of the exciton but do not affect dramatically the energetics of the MLCT state nor that of the metal-centered MC state.

The emission spectra of the $\left[\mathrm{Os}_{-} \mathrm{ph}_{5}-\mathrm{Os}\right]^{4+}$ and [Os-Flu$\mathrm{Os}]^{4+}$ complexes and the reference compound $\left[\mathrm{Os}(\mathrm{bpy})_{3}\right]^{2+}$ in acetonitrile solution are shown in Figure 4. For the osmium bimetallic complexes, the maximum of emission is around $745 \mathrm{~nm}$ and shows only a slight red-shift compared to [Os$\left.(\text { bpy })^{3}\right]^{2+}(743 \mathrm{~nm})$. The emission for both systems containing the different bridging ligands is similar and exhibits a typical ${ }^{3}$ MLCT character. As in the case of the ruthenium complexes, the osmium compounds have all the same excited state lifetimes (see Table 2) at room temperature and show only a weak, not spectroscopic visible, electronic interaction between the two terminal units.

At $77 \mathrm{~K}$, in glassy butyronitrile matrixes, all the complexes exhibit a structured emission with a maximum centered on 595 and $720 \mathrm{~nm}$ for the ruthenium and osmium complexes, respectively (see Figures 3 and 4 insets and Tables 1 and $2)$. It is interesting to notice that for both series there is a red-shift in the dinuclear species compared to $\left[\mathrm{Ru}(\mathrm{bpy})_{3}\right]^{2+}$ and $\left[\mathrm{Os}(\mathrm{bpy})_{3}\right]^{2+}$. Furthermore, the shortest member of the families, the compounds containing only two phenylene units

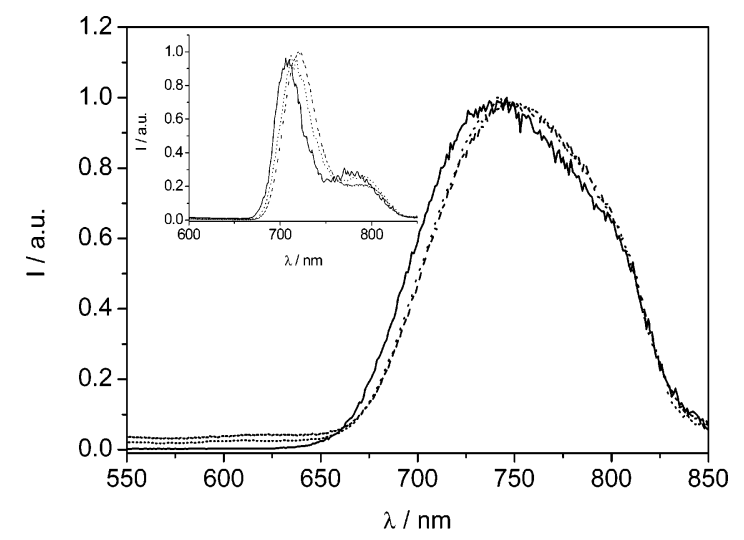

Figure 4. Luminescence spectra of the complexes $\left[\mathrm{Osbpy}_{3}\right]^{2+}(-)$,

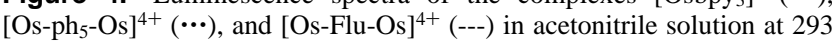
$\mathrm{K}\left(\lambda_{\mathrm{exc}}=435 \mathrm{~nm}\right)$. The inset shows the emission spectra at $77 \mathrm{~K}$ in butyronitrile rigid matrix of $\left[\mathrm{Osbpy}_{3}\right]^{2+}(-),[\mathrm{O} b \mathrm{spy}-\mathrm{ph}-\mathrm{Br}]^{2+}(\cdots)$, and $\left[\mathrm{Os}-\mathrm{ph}_{2}-\mathrm{Os}\right]^{4+}(---)$.

in the bridging ligand, are slightly red-shifted compared with the corresponding mononuclear complexes, [Rubpy- $\mathrm{ph}_{2^{-}}$ $\mathrm{bpy}^{2+}(590 \mathrm{~nm})$, suggesting a weak but nonnegligible electronic interaction between the two metal centers. The emission lifetimes of the ruthenium complexes at low temperature are relatively long (6.1 to $6.4 \mu \mathrm{s}$ ) compared with that of the reference compound $\left[\mathrm{Ru}(\mathrm{bpy})_{3}\right]^{2+}(4.8 \mu \mathrm{s})$. Again, such data indicate a strong contribution of the delocalization due to the presence of the conjugated moieties on the bipyridine and that the lowest excited state is localized on the bridging ligand. A similar behavior is observed for the osmium dinuclear complexes.

Transient Absorption Spectroscopy. More detailed information about the electronic nature of the lowest excited state is provided by time-resolved transient absorption spectroscopy. Upon excitation, both in the ruthenium and osmium tris-bipyridine complexes, the lowest excited state is an MLCT state. A charge is formally localized on the bpy ligand with the lowest reduction potential, and the ruthenium or osmium unit is formally oxidized. In a differential transient spectrum this can be easily visualized by the appearance of a bleaching corresponding to the ${ }^{1}$ MLCT band in the absorbance spectrum and formation of the bands corresponding to the bipyridine radical anion, bpy ${ }^{\circ-}$. If the bridging ligand is involved in the excitation, it is expected that the transient absorption spectra of $\left[\mathrm{Ru}(\mathrm{bpy})_{3}\right]^{2+}$ and the dinuclear complexes would differ. Figure 5 displays the transient absorption spectra of $\left[\mathrm{Ru}(\mathrm{bpy})_{3}\right]^{2+}$ (Figure 5a) and $\left[\mathrm{Ru}-\mathrm{ph}_{4^{-}}\right.$ $\mathrm{Ru}]^{4+}$ (Figure 5b). All the other dinuclear complexes show similar features as $\left[\mathrm{Ru}-\mathrm{ph}_{4}-\mathrm{Ru}\right]^{4+}$. In the spectra, the negative band at $460 \mathrm{~nm}$ is due to the bleaching of the ground state of the $\mathrm{Ru}(\mathrm{bpy})_{3}$ moieties of the complexes $\left(\mathrm{d} \pi \rightarrow \pi^{*}\right.$ transition). In the case of $[\mathrm{Ru}-\mathrm{Flu}-\mathrm{Ru}]^{4+}$, this bleaching band is more structured and shows the bleaching of the indenofluorene unit (Figure 5c). The strong absorption band at 375 $\mathrm{nm}$ is due to the formation of the $\mathrm{bpy}^{\mathbf{0}^{-}}$radical anion, since the MLCT state is the lowest excited state. An additional intense and very broad feature appears in the region from 500 to $850 \mathrm{~nm}$ for $\left[\mathrm{Ru}-\mathrm{ph}_{4}-\mathrm{Ru}\right]^{4+}$ and $[\mathrm{Ru}-\mathrm{Flu}-\mathrm{Ru}]^{4+}$ with a lifetime of $200 \mathrm{~ns}$ corresponding to the emission decay. A more extended delocalization of the excited state, due to the 
Welter et al.
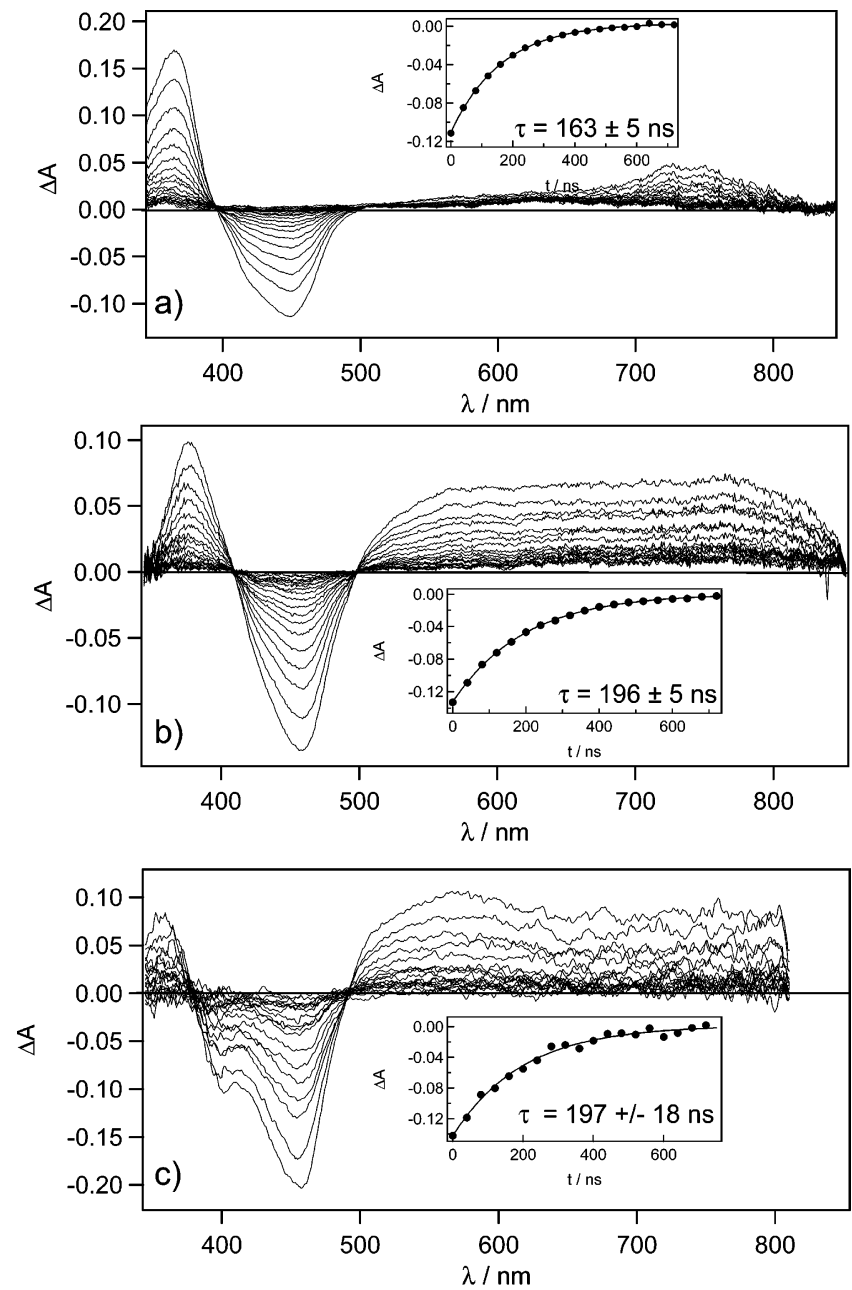

Figure 5. Transient absorption spectra of $\left[\mathrm{Ru}(\mathrm{bpy})_{3}\right]^{2+}(\mathrm{a}),\left[\mathrm{Ru}-\mathrm{ph} \mathrm{h}_{4}-\mathrm{Ru}\right]^{4+}$ (b), and $[\mathrm{Ru}-\mathrm{Flu}-\mathrm{Ru}]^{4+}(\mathrm{c})$ recorded in acetonitrile $\left(\lambda_{\mathrm{exc}}=435 \mathrm{~nm}\right)$. The insets show the recovery of the ground-state bleaching.

presence of the oligophenylene structure, is responsible for this absorption at lower energy. This was reported for other conjugated structures. ${ }^{27}$ The intensity and energy of this band depend partially on the number of phenylenes. By comparison with $\left[\mathrm{Ru}(\mathrm{bpy})_{3}\right]^{2+}$ the difference is clearly seen as a shift to lower energy of the bpy $^{--}$band around $380 \mathrm{~nm}$ and, in the case of the unsubstituted bpy, a lack of such broad feature in the visible. It is interesting to notice that such a band does not change going from 3 to 5 phenylene units, probably because the first 2 phenylene units are the only responsible for the delocalization of the charge. Furthermore, the fact that the excited state is localized on the bridging ligand, and therefore directional, can be employed for vectorial energy or electron transport in non covalently linked systems. ${ }^{64} \mathrm{It}$ is worth mentioning that the different planarization of the $p$-phenylene units versus the indenofluorene derivatives does not seem to play a major role. Such a behavior could be explained by the fact that in the excited state the phenylenes become planar despite the fact that in the ground state the tilt angle is $23^{\circ}$. On the other hand, however, the HOMOLUMO gap for the indenofluorene spacer is expected to be lower and could play a major role in systems where energy or electron transfer take place.
Table 3. Electrochemical Data for the Dinuclear Ruthenium Complexes $^{a}$

\begin{tabular}{|c|c|c|c|c|}
\hline \multirow[b]{3}{*}[\mathrm{Ru}-\mathrm{ph}_{2}-\mathrm{Ru}]{$^{4+}$} & \multicolumn{4}{|c|}{$E_{1 / 2}(\mathrm{~V})$} \\
\hline & \multirow{2}{*}{$\frac{\mathrm{Ru}(\mathrm{II} / \mathrm{III})}{+1.27}$} & \multicolumn{3}{|c|}{ bpy } \\
\hline & & -1.31 & -1.52 & -1.84 \\
\hline$\left[\mathrm{Ru}-\mathrm{ph}_{3}-\mathrm{Ru}\right]^{4+}$ & +1.27 & -1.31 & -1.53 & -1.84 \\
\hline$\left[\mathrm{Ru}-\mathrm{ph}_{4}-\mathrm{Ru}\right]^{4+}$ & +1.28 & -1.30 & -1.52 & -1.83 \\
\hline$\left[\mathrm{Ru}-\mathrm{ph}_{5}-\mathrm{Ru}\right]^{4+}$ & +1.26 & -1.31 & -1.51 & -1.84 \\
\hline$[R u-F l u-R u]^{4+}$ & +1.28 & -1.30 & -1.51 & -1.84 \\
\hline$\left[\mathrm{Ru}(\mathrm{bpy})_{3}\right]^{2+}$ & +1.28 & -1.33 & -1.56 & -1.87 \\
\hline
\end{tabular}

${ }^{a}$ Butyronitrile solution with $0.1 \mathrm{M} \mathrm{Bu}_{4} \mathrm{NPF}_{6}$, room temperature, potential values vs SCE.

Table 4. Electrochemical Data for the Dinuclear Osmium Complexes ${ }^{a}$

\begin{tabular}{|c|c|c|c|c|}
\hline \multirow[b]{3}{*}[\mathrm{Os}-\mathrm{ph}_{2}-\mathrm{Os}]{$^{4+}$} & \multicolumn{4}{|c|}{$E_{1 / 2}(\mathrm{~V})$} \\
\hline & \multirow{2}{*}{$\frac{\mathrm{Os}(\mathrm{II} / \mathrm{III})}{+0.86}$} & \multicolumn{3}{|c|}{ bpy } \\
\hline & & -1.20 & -1.42 & -1.78 \\
\hline$\left[\mathrm{Os}-\mathrm{ph}_{3}-\mathrm{Os}\right]^{4+}$ & +0.83 & -1.23 & -1.45 & -1.83 \\
\hline$\left[\mathrm{Os}-\mathrm{ph}_{4}-\mathrm{Os}\right]^{4+}$ & +0.84 & -1.24 & -1.46 & -1.86 \\
\hline$\left[\mathrm{Os}-\mathrm{ph}_{5}-\mathrm{Os}\right]^{4+}$ & +0.83 & -1.23 & -1.45 & -1.87 \\
\hline [Os-Flu-Os] $^{4+}$ & +0.86 & -1.20 & -1.42 & -1.79 \\
\hline$\left[\mathrm{Os}(\mathrm{bpy})_{3}\right]^{2+}$ & +0.85 & -1.20 & -1.41 & -1.77 \\
\hline
\end{tabular}

${ }^{a}$ Butyronitrile solution with $0.1 \mathrm{M} \mathrm{Bu}_{4} \mathrm{NPF}_{6}$, room temperature, potential values vs SCE.

Electrochemical Measurements. Electrochemical studies employed cyclic voltammetry with a three-electrode system consisting of a platinum working electrode, a platinum counter electrode, and a silver pseudo-reference electrode. The electrochemical data for the ruthenium compounds and $\left[\mathrm{Ru}(\mathrm{bpy})_{3}\right]^{2+}$ are reported in Table 3 . Corresponding data for osmium compounds and $\left[\mathrm{Os}(\mathrm{bpy})_{3}\right]^{2+}$ are reported in Table 4.

All the dinuclear complexes have a single, reversible bielectronic anodic wave for the $\mathrm{Ru}(\mathrm{II} / \mathrm{III})$ and $\mathrm{Os}(\mathrm{II} / \mathrm{III})$ redox couple, almost at the same potential as for the reference compounds, $\left[\mathrm{Ru}(\mathrm{bpy})_{3}\right]^{2+}$ and $\left[\mathrm{Os}(\mathrm{bpy})_{3}\right]^{2+}$. This supports the fact that the electronic coupling between the metal centers is relatively weak. All the complexes exhibit three wellresolved reversible waves in the cathodic branch of the voltammograms that are due to reductions centered on the substituted and unsubstituted bipyridine ligands. For each of the ruthenium complexes, the first reduction is shifted to a more positive potential than the first reduction of $[\mathrm{Ru}-$ $\left.(\text { bpy })_{3}\right]^{2+}$. This feature indicates that for the dinuclear complexes the first reduction is localized on the phenylenesubstituted bipyridine.

Crystal Structure. For the precursor $\left[\mathrm{Rubpy}-\mathrm{ph}_{2}-\mathrm{Si}-\right.$ $\left.\left(\mathrm{CH}_{3}\right)_{3}\right]\left(\mathrm{PF}_{6}\right)_{2}$, single crystals were obtained by recrystallization from methanol. The crystal structure is shown in Figure 6; crystal and unit cell data as well as selected bond distances and angles are presented in Tables 5 and 6 , respectively. Besides the main molecules, the structure additionally contains disordered solvent molecules, which were treated as diffuse electron density (see Experimental Section). The three bipyridyl residues are approximately coplanar with interplanar angles of 3.3(4), 11.3(5), and $1.4(4)^{\circ}$, respectively. Most importantly, the crystal structure reveals that the first phenyl ring makes a dihedral angle of $22.0(4)^{\circ}$ with the bipyridine plane, whereas the second phenyl ring is almost coplanar with the bipyridine unit (dihedral 


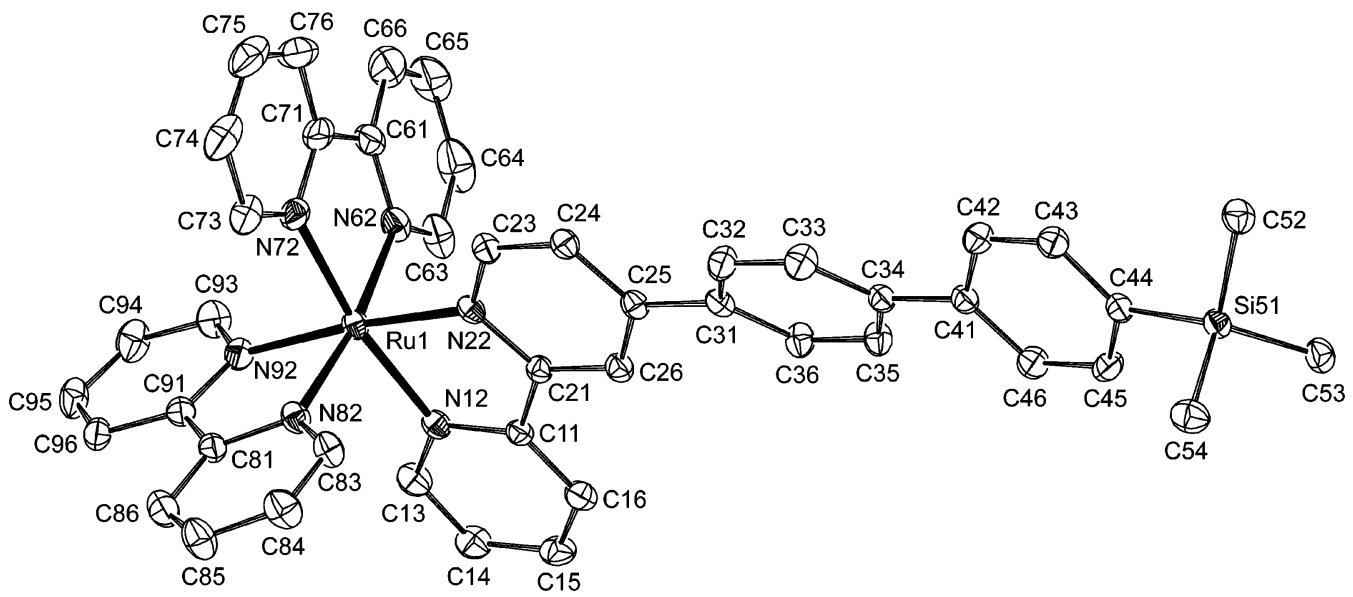

Figure 6. Displacement ellipsoid plot (30\% probability) of [Rubpy-ph $\left.{ }_{2}-\mathrm{Si}\left(\mathrm{CH}_{3}\right)_{3}\right]\left(\mathrm{PF}_{6}\right)_{2}$. Hydrogen atoms, $\mathrm{PF}_{6}{ }^{-}$anions, and disordered solvent molecules have been omitted for clarity.

Table 5. Crystal and Unit Cell Data for $\left[\right.$ Rubpy- $\left.\mathrm{ph}_{2}-\mathrm{Si}\left(\mathrm{CH}_{3}\right)_{3}\right]\left(\mathrm{PF}_{6}\right)_{2}$

\begin{tabular}{|c|c|}
\hline formula & $\mathrm{C}_{45} \mathrm{H}_{40} \mathrm{~F}_{12} \mathrm{~N}_{6} \mathrm{P}_{2} \mathrm{RuSi}+$ disordered solvent \\
\hline formula weight $^{a}$ & 1083.93 \\
\hline crystal system & triclinic \\
\hline space group & $\mathrm{P} \overline{1}($ No. 2) \\
\hline$a / \AA$ & $11.6477(2)$ \\
\hline$b / \AA ̊$ & $11.7793(2)$ \\
\hline$c / \AA$ & $19.5014(3)$ \\
\hline$\alpha / \operatorname{deg}$ & $75.8460(6)$ \\
\hline$\beta / \mathrm{deg}$ & $77.0381(6)$ \\
\hline$\gamma / \mathrm{deg}$ & $75.8165(7)$ \\
\hline$V / \AA^{3}$ & $2476.56(7)$ \\
\hline $\mathrm{Z}$ & 2 \\
\hline$D_{\text {cald }} / \mathrm{g} \mathrm{m}^{-3 a}$ & 1.454 \\
\hline$\mu / \mathrm{mm}^{-1 a}$ & 0.488 \\
\hline$F(000)^{a}$ & 1096 \\
\hline crystal size/mm & $0.09 \times 0.12 \times 0.27$ \\
\hline$(\sin \theta / \lambda)_{\max } / \AA^{-1}$ & 0.53 \\
\hline measured reflections & 28011 \\
\hline unique reflections & 6088 \\
\hline$R_{\text {int }}$ & 0.041 \\
\hline parameters/restraints & $622 / 127$ \\
\hline$R 1[I>2 \sigma(I)]$ & 0.0671 \\
\hline$w R 2$ [all refl.] & 0.1892 \\
\hline GoF & 1.081 \\
\hline
\end{tabular}

${ }^{a}$ Derived quantities do not contain the contribution of the disordered solvent.

Table 6. Selected Distances $(\AA)$, Angles $\left({ }^{\circ}\right)$, and Torsion Angles $\left({ }^{\circ}\right)$ for $\left[\mathrm{Rubpy}-\mathrm{ph}_{2}-\mathrm{Si}\left(\mathrm{CH}_{3}\right)_{3}\right]\left(\mathrm{PF}_{6}\right)_{2}$

$\begin{array}{lr}\mathrm{Ru}(1)-\mathrm{N}(12) & 2.061(6) \\ \mathrm{Ru}(1)-\mathrm{N}(22) & 2.069(6) \\ \mathrm{Ru}(1)-\mathrm{N}(62) & 2.064(6) \\ \mathrm{Ru}(1)-\mathrm{N}(72) & 2.057(6) \\ \mathrm{Ru}(1)-\mathrm{N}(82) & 2.052(6) \\ \mathrm{Ru}(1)-\mathrm{N}(92) & 2.062(6) \\ \mathrm{N}(12)-\mathrm{Ru}(1)-\mathrm{N}(22) & 78.6(2) \\ \mathrm{N}(62)-\mathrm{Ru}(1)-\mathrm{N}(72) & 79.3(3) \\ \mathrm{N}(82)-\mathrm{Ru}(1)-\mathrm{N}(92) & 78.9(2) \\ \mathrm{C}(24)-\mathrm{C}(25)-\mathrm{C}(31)-\mathrm{C}(32) & 22.4(10) \\ \mathrm{C}(33)-\mathrm{C}(34)-\mathrm{C}(41)-\mathrm{C}(32) & -24.2(11)\end{array}$

angle $\left.6.9(4)^{\circ}\right)$. This geometry ensures a good conjugation of their $\pi$ systems. The $\mathrm{Ru}-\mathrm{N}$ bond lengths range from 2.052(6) $\AA$ for $\mathrm{Ru}-\mathrm{N}(82)$ to 2.069(6) $\AA$ for $\mathrm{Ru}-\mathrm{N}(22)$. This might indicate that there is less electron density on $\mathrm{N}(22)$ because of a higher conjugation of the bipyridine unit and the phenylene in para position.

\section{Experimental Section}

General. Reagents and solvents were all commercially available and used as received. The ligand 4-(4-bromo-phenyl)-[2,2']bi- pyridinyl ${ }^{66}$ and $4,4^{\prime \prime}$-dibromo- $\left[1,1^{\prime} ; 4^{\prime}, 1^{\prime \prime}\right]$ terphenyl, ${ }^{67}$ [Rubpyph-Br $]^{2+},\left[\mathrm{Rubpy}-\mathrm{ph}_{2}-\mathrm{Si}\left(\mathrm{CH}_{3}\right)_{3}\right]^{2+},\left[\mathrm{Rubpy}-\mathrm{ph}_{2}-\mathrm{I}\right]^{2+} 64$ and 2,8-bis(4,4,5,5-tetramethyl-1,3,2-dioxaborolan-2-yl)tetraalkylindeno-(1,2b)fluorene ${ }^{68}$ were prepared following literature procedures. All experiments were carried out under $\mathrm{N}_{2}$ atmosphere using standard Schlenk line techniques except where otherwise mentioned. Chromatographic purification was conducted using $40-63-\mu \mathrm{m}$ silica gel or neutral alumina $705 \mathrm{C}$ purchased from Fluka. Preparative thicklayer chromatography was performed on ANALTECH silica gel G Uniplates (soft layer, $20 \times 20 \mathrm{~cm}, 1000 \mu \mathrm{m}$ ). NMR spectra were recorded on a Varian Mercury-VX (300 MHz) using the residual nondeuterated solvent as reference in the case of ${ }^{1} \mathrm{H}$ NMR. Highresolution electron spray ionizaton (ESI) mass spectra were measured with a Bruker FTMS 4.7 T Bio APEXII spectrometer. Fast atom bombardment mass spectroscopy (MS-FAB) was performed with a Vacuum Micromass VG 70/70E (nitrobenzyl alcohol matrix).

Photophysical Measurements. Absorption and emission spectra were obtained on air-equilibrated solutions using previously described equipment. ${ }^{69}$ Time-resolved emission spectra were measured on a Hamamatsu C-5680 streak camera equipped with a M 5677 sweep unit. Excitation at $450 \mathrm{~nm}$ was achieved by a pulsed Coherent Infinity XPO laser operating at a repetition rate of 10 $\mathrm{Hz}$. The time resolution of this setup is about $200 \mathrm{ps}$, as limited by the laser width. Estimated errors are as follows: band maxima, $\pm 2 \mathrm{~nm}$; relative luminescence intensity, $\pm 20 \%$; lifetimes, $\pm 10 \%$.

Transient Absorption Spectroscopy. Nanosecond transient absorption spectra were obtained by irradiating the samples with 2-ns pulses (fwhm) of a continuously tunable $(420-710 \mathrm{~nm})$ Coherent Infinity XPO laser using a setup that was reported previously. ${ }^{69}$ All spectra were recorded in acetonitrile with $80 \mathrm{~ns}$ between each frame with a minimum instrumental gate time of 5 ns. The first frame was recorded $1 \mathrm{~ns}$ after the laser pulse. Samples were prepared to have optical density, at the excitation wavelength, of about 0.5 in a 1 -cm cuvette.

Electrochemical Measurements. Electrochemical studies were performed using a PAR model 283 potentiostat employing a gas-

(66) Querol, M.; Bozic, B.; Salluze, N.; Belser, P. Polyhedron 2003, 22, 655-664.

(67) Colonge, J.; Buendia, J.; Sabadie, J. Bull. Soc. Chim. Fr. 1967, 11, $4370-4374$

(68) Sonar, P.; Zhang, J.; Grimsdale, A. C.; Müllen, K.; Surin, M.; Lazzaroni, R.; Leclère, S.; Tierney, S.; Heeney, M.; McCulloch, I. Macromol. 2004, 37, 709-715.

(69) Kleverlaan, C. J.; Stufkens, D. J.; Clark, I. P.; George, M. W.; Turner, J. J.; Martino, D. M.; van Willigen, H.; Vlcek, J. J. Am. Chem. Soc. 1998, 120, 10871-10879. 
tight, single-compartment, three-electrode cell under an argon atmosphere. A platinum disk (apparent surface area of $0.42 \mathrm{~mm}^{2}$ ) was employed as the working electrode. Before each measurement the electrode was polished with diamond paste. A silver wire and a platinum wire were used as pseudoreference and auxiliary electrodes, respectively. The redox potentials were measured against the ferrocene/ferrocenium $\left(\mathrm{Fc} / \mathrm{Fc}^{+}\right)$redox couple that was used as an internal standard $\left(E_{1 / 2}=0.38 \mathrm{~V}\right.$ vs SCE in acetonitrile). Tetrabutylammonium hexafluorophosphate $(0.1 \mathrm{M})$ was used as supporting electrolyte.

Crystal Structure Determination of [Rubpy-ph $\left.2-\mathrm{Si}\left(\mathrm{CH}_{3}\right)_{3}\right]-$ $\left(\mathbf{P F}_{6}\right)_{2}$. X-ray intensities were measured on a Nonius Kappa CCD diffractometer with rotating anode (graphite monochromator, $\lambda=$ $0.71073 \AA$ ) at a temperature of $150(2) \mathrm{K}$. An absorption correction was not considered necessary. The structure was solved with automated Patterson methods ${ }^{70}$ and refined with SHELXL-97 ${ }^{71}$ against $\mathrm{F}^{2}$ of all reflections. Non-hydrogen atoms were refined freely with anisotropic displacement parameters. Hydrogen atoms were introduced in calculated positions and refined as rigid groups. One $\mathrm{PF}_{6}{ }^{-}$anion was refined with a disorder model. The crystal structure contains voids (306 $\AA^{3} /$ unit cell) filled with disordered solvent molecules. Their contribution to the structure factors (78 electrons/ unit cell) was secured by back-Fourier transformation using the SQUEEZE procedure of the PLATON package. ${ }^{72}$ Structure calculations, drawings, and checking for higher symmetry were performed with PLATON. ${ }^{72}$ Further crystallographic details are given in Table 5 .

Synthesis. Bpy-ph-B $(\mathrm{OR})_{2}$ [12], 4-[4-(4,4,5,5-Tetramethyl$[1,3,2]$ dioxaborolan-2-yl)-phenyl]-[2,2']bipyridinyl. The ligand bpy-ph-Br [11] (105 mg, $0.34 \mathrm{mmol})$, oven-dried potassium acetate (99 mg, $1.01 \mathrm{mmol}$ ), and bis(pinacolato)diboron (99 mg, 0.39 $\mathrm{mmol})$ were dissolved in DMSO $(2 \mathrm{~mL})$, and oxygen was removed from the system by the freeze-pump-thaw technique. The catalyst, $\mathrm{PdCl}_{2}$ (dppf) ( $\left.8.3 \mathrm{mg}, 0.01 \mathrm{mmol}\right)$, was added; the reaction mixture was then heated to $105{ }^{\circ} \mathrm{C}$ for $17 \mathrm{~h}$. After cooling to room temperature, $3 \mathrm{~mL}$ of water were added to the dark-brown-reddish solution. The resulting mixture was then extracted with $\mathrm{CH}_{2} \mathrm{Cl}_{2}(2$ $\times 20 \mathrm{~mL}$ ). The combined brownish-colored organic layer was washed with water until the water phase became colorless. The organic phase was evaporated under reduced pressure to afford a black solid. Extraction with hexane isolated the desired compound which was used without further purification (yield: $111 \mathrm{mg}, 85 \%$ ). ${ }^{1} \mathrm{H}$ NMR $\left(300 \mathrm{MHz}, \mathrm{CDCl}_{3}\right): \delta=8.74(\mathrm{~m}, 2 \mathrm{H}), 8.71(\mathrm{~s}, 1 \mathrm{H})$, $8.47(\mathrm{~d}, J=7.6 \mathrm{~Hz}, 1 \mathrm{H}), 7.96(\mathrm{~d}, J=8.1 \mathrm{~Hz}, 2 \mathrm{H}), 7.86(\mathrm{dd}, J=$ $7.6 \mathrm{~Hz}, 2.0 \mathrm{~Hz}, 1 \mathrm{H}), 7.80(\mathrm{~d}, J=8.5 \mathrm{~Hz}, 2 \mathrm{H}), 7.58(\mathrm{dd}, J=5.0$ $\mathrm{Hz}, 2.0 \mathrm{~Hz}, 1 \mathrm{H}$ ), 7.35 (ddd, $J=7.6 \mathrm{~Hz}, 4.5 \mathrm{~Hz}, 1.0 \mathrm{~Hz}, 1 \mathrm{H}), 1.4$ (s, $12 \mathrm{H}) .{ }^{13} \mathrm{C}$ NMR $\left(100 \mathrm{MHz}, \mathrm{CDCl}_{3}\right): \delta=157.1,156.5,150.0$, 149.6, 141.2, 137.4, 135.9, 135.1, 126.8, 124.2, 122.1, 121.8, 119.5, 84.2, 25.5, 25.0. MS (FAB, $m / z): 359(\mathrm{M}+\mathrm{H})^{+}$.

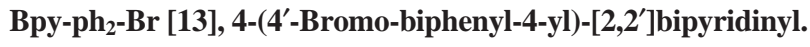
An oven-dried two-neck round flask was charged with bpy-ph$\mathrm{B}(\mathrm{OR})_{2}$ [12] (450 mg, $1.26 \mathrm{mmol}$ ) and 1-bromo-4-iodo-benzene (355 mg, $1.26 \mathrm{mmol}$ ). The flask was evacuated and backfilled with argon for four cycles. Degassed toluene $(13 \mathrm{~mL}), \mathrm{Na}_{2} \mathrm{CO}_{3} 1 \mathrm{M}$ in $\mathrm{H}_{2} \mathrm{O}(13 \mathrm{~mL}, 12.6 \mathrm{mmol})$, and $\mathrm{Pd}\left(\mathrm{PPh}_{3}\right)_{4}(12 \mathrm{mg}, 0.01 \mathrm{mmol})$ were

(70) Beurskens, P. T.; Admiraal, G.; Beurskens, G.; Bosman, W. P.; GarciaGranda, S.; Gould, R. O.; Smits, J. M. M.; Smykalla, C. "The DIRDIF99 program system, Technical Report of the Crystallography Laboratory," The Netherlands, 1999.

(71) Sheldrick, G. M. SHELXL-97. Program for crystal structure refinement, Universität Göttingen, Germany, 1997.

(72) Spek, A. L. J. Appl. Crystallogr. 2003, 36, 7-13.

(73) Calvert, J. M.; Caspar, J. V.; Binstead, R. A.; Westmoreland, T. D.; Meyer, T. J. J. Am. Chem. Soc. 1982, 104, 6620-6627. added under a mild flow of argon. The reaction mixture was heated at $95{ }^{\circ} \mathrm{C}$ for $48 \mathrm{~h}$. The reaction mixture was cooled to room temperature. The layers were separated, and the aqueous layer was extracted with toluene $(2 \times 20 \mathrm{~mL})$. The combined organic phases were dried $\left(\mathrm{MgSO}_{4}\right)$ and evaporated under reduced pressure to yield a yellow solid. The crude product was dissolved in $\mathrm{CH}_{2} \mathrm{Cl}_{2}(3 \mathrm{~mL})$ and purified over silica gel column chromatography (Kieselgel 60, 230-400 mesh ASTM deactivated by triethylamine, $12 \times 3 \mathrm{~cm}$ ) using $\mathrm{CH}_{2} \mathrm{Cl}_{2}$ /EtOAC (4:1) as eluent. After evaporation of the solvents the desired compound was obtained as a white solid (yield: $342 \mathrm{mg}, 70 \%) .{ }^{1} \mathrm{H} \mathrm{NMR}\left(400 \mathrm{MHz}, \mathrm{CDCl}_{3}\right): \delta=8.79(\mathrm{~m}$, $3 \mathrm{H}), 8.58(\mathrm{~d}, J=8.6 \mathrm{~Hz}, 1 \mathrm{H}), 7.91(\mathrm{~d}, J=8.1 \mathrm{~Hz}, 3 \mathrm{H}), 7.73$ (d, $J=8.6 \mathrm{~Hz}, 2 \mathrm{H}), 7.66(\mathrm{dd}, J=1.5 \mathrm{~Hz}, 5.1 \mathrm{~Hz}, 1 \mathrm{H}), 7.63(\mathrm{~d}, J=$ $8.6 \mathrm{~Hz}, 2 \mathrm{H}), 7.54(\mathrm{~d}, J=8.1 \mathrm{~Hz}, 2 \mathrm{H}), 7.41(\mathrm{~m}, 1 \mathrm{H}) .{ }^{13} \mathrm{C} \mathrm{NMR}$ $\left(100 \mathrm{MHz}, \mathrm{CDCl}_{3}\right): \delta=156.2,155.4,149.5,144.1,142.8,141.4$, 139.5, 137.9, 137.4, 132.4, 129.3, 129.1, 128.2, 127.5, 124.6, 122.5, 122, 121.5, 119.7. MS (FAB, $m / z): 387.05(\mathrm{M}+\mathrm{H})^{+}$.

Bpy-ph 2 -B(OR) 2 [14], 4-[4'-(4,4,5,5-Tetramethyl-[1,3,2]dioxaborolan-2-yl]-biphenyl-4-yl]-[2,2']bipyridinyl. A solution of bpy$\mathrm{ph}_{2}-\mathrm{Br}$ [13] (90 mg, $\left.0.24 \mathrm{mmol}\right)$, oven-dried potassium acetate (66 $\mathrm{mg}, 0.67 \mathrm{mmol})$, and bis(pinacolato)diboron $(65 \mathrm{mg}, 0.26 \mathrm{mmol})$ in DMSO (3 mL) was evacuated and backfilled with argon (four cycles). Finally, $\mathrm{PdCl}_{2}(\mathrm{dppf})(8.3 \mathrm{mg}, 0.01 \mathrm{mmol})$ was added over a mild flow of argon. The reaction mixture was heated to $105^{\circ} \mathrm{C}$ for $25 \mathrm{~h}$. Water $(3 \mathrm{~mL})$ was added to the dark-brown-reddish solution, and the resulting mixture was extracted with $\mathrm{CH}_{2} \mathrm{Cl}_{2}(2$ $\times 20 \mathrm{~mL}$ ). The combined brownish organic layer was washed with water $(4 \times 10 \mathrm{~mL})$ until the water phase became colorless. The organic phase was evaporated under reduced pressure to afford a black solid. Addition of hexane to this solid solubilized the desired compound that was used without further purification (yield: 98 mg, 94\%). ${ }^{1} \mathrm{H}$ NMR (400 MHz, $\mathrm{CDCl}_{3}$ ): $\delta=8.79$ (m, 3H), 8.58 $(\mathrm{d}, J=8.1 \mathrm{~Hz}, 1 \mathrm{H}), 7.92(\mathrm{~m}, 5 \mathrm{H}), 7.79(\mathrm{~d}, J=8.1 \mathrm{~Hz}, 2 \mathrm{H}), 7.68$ $(\mathrm{m}, 3 \mathrm{H}), 7.40(\mathrm{ddd}, J=8.1 \mathrm{~Hz}, 5.6 \mathrm{~Hz}, 1.0 \mathrm{~Hz}, 1 \mathrm{H}), 1.4(\mathrm{~s}, 12 \mathrm{H})$. ${ }^{13} \mathrm{C}$ NMR (100 MHz, $\left.\mathrm{CDCl}_{3}\right): \delta=149.4,143.2,142.5,137.8$, $137.3,135.8,135.1,129.3,128.3,128.1,127.5,126.8,124.6,122.2$, 122.0, 119.7, 84.3, 83.9, 25.4, 25.2. HRMS (ESI), $m / z:[\mathrm{M}+\mathrm{H}]^{+}$ calcd for $\mathrm{C}_{28} \mathrm{H}_{28} \mathrm{~N}_{2} \mathrm{~B}(11) \mathrm{O}_{2}$ : 435.2238; found: 435.2235 .

Bpy-ph 2 -bpy [15]. A dry flask was charged with bpy-ph-B(OR) [12] (193 mg, $0.54 \mathrm{mmol})$, bpy-ph-Br [11] (146 mg, $0.47 \mathrm{mmol}$ ), and $\mathrm{K}_{2} \mathrm{CO}_{3}(500 \mathrm{mg}, 3.61 \mathrm{mmol})$. The flask was evacuated and backfilled with argon (four cycles). Degassed DMF (20 mL) and $\mathrm{Pd}\left(\mathrm{PPh}_{3}\right)_{4}(12 \mathrm{mg}, 0.01 \mathrm{mmol})$ were added over a mild flow of argon. The reaction mixture was heated at $120{ }^{\circ} \mathrm{C}$ for $20 \mathrm{~h}$. The reaction mixture was then cooled to room temperature; more $\mathrm{DMF}$ $(10 \mathrm{~mL})$ was then added to precipitate more of the free ligand, which was isolated by suction filtration and washed with DMF (2 $\times 10 \mathrm{~mL})$. The crude product was dissolved in $\mathrm{CH}_{2} \mathrm{Cl}_{2}(3 \mathrm{~mL})$ and purified using column chromatography $\left(\mathrm{SiO}_{2}, \mathrm{CH}_{2} \mathrm{Cl}_{2} / \mathrm{MeOH}\right.$ (9:1) as eluent). The fractions containing the desired compound [TLC: $R_{f}=0.10$, support $\mathrm{SiO}_{2}, \mathrm{CH}_{2} \mathrm{Cl}_{2} / \mathrm{MeOH}$ (9:1) as eluent], were collected and evaporated under reduced pressure to yield a white solid (yield: $120 \mathrm{mg}, 55 \%) .{ }^{1} \mathrm{H} \mathrm{NMR}\left(400 \mathrm{MHz}, \mathrm{CDCl}_{3}\right): \delta$ $=8.58(\mathrm{~m}, 4 \mathrm{H}), 8.52(\mathrm{~s}, 2 \mathrm{H}), 8.23(\mathrm{~d}, J=8.0 \mathrm{~Hz}, 2 \mathrm{H}), 7.80(\mathrm{~d}, J$ $=8.5 \mathrm{~Hz}, 6 \mathrm{H}), 7.70(\mathrm{~d}, J=8.5 \mathrm{~Hz}, 4 \mathrm{H}), 7.55(\mathrm{dd}, J=5.3 \mathrm{~Hz}, 1.8$ $\mathrm{Hz}, 2 \mathrm{H}), 7.32-7.24(\mathrm{~m}, 2 \mathrm{H}) .{ }^{13} \mathrm{C}$ NMR $\left(75 \mathrm{MHz}, \mathrm{CDCl}_{3}\right): \delta=$ 157.3, 156.1, 149.6, 149.0, 148.85, 146.3, 137.14, 132.27, 128.3, 124.2, 123.5, 121.4, 121.2, 118.8. MS (FAB, $m / z): 463(\mathrm{M}+\mathrm{H})^{+}$. HRMS (ESI), $m / z:[\mathrm{M}+\mathrm{H}]^{+}$calcd for $\mathrm{C}_{32} \mathrm{H}_{23} \mathrm{~N}_{4}: 463.1917$; found: 463.1911.

Bpy-ph ${ }_{4}$-bpy [16]. A dry flask was charged with bpy-ph ${ }_{2}-\mathrm{Br}$ [13] (302 mg, $0.78 \mathrm{mmol})$ and bpy-ph ${ }_{2}-\mathrm{B}(\mathrm{OR})_{2}$ [14] (280 mg, 0.78 $\mathrm{mmol}$ ). Oxygen was removed from the closed system by evacuation 
and argon backfilling (four cycles). To this system, degassed toluene ( $7 \mathrm{~mL}$ ) and a degassed aqueous solution of $\mathrm{Na}_{2} \mathrm{CO}_{3} 1 \mathrm{M}(7 \mathrm{~mL}, 7$ mmol) and $\mathrm{Pd}\left(\mathrm{PPh}_{3}\right)_{4}(0.04 \mathrm{~mol} \%)$ were added over a mild flow of argon. The reaction mixture was refluxed for $50 \mathrm{~h}$. The solution was cooled to room temperature, and the insoluble solid was recovered by suction filtration and washed with hexane $(2 \times 20$ $\mathrm{mL}$ ). The crude product was used in the next step without further purification (yield: $417 \mathrm{mg}, 87 \%$ ).

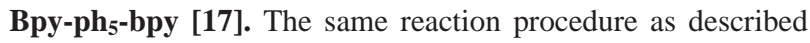
for bpy-ph 4 -bpy was used, using 4,4"'-dibromo-[1,1'; $\left.4^{\prime}, 1^{\prime \prime}\right]$ terphenyl (100 mg, $0.26 \mathrm{mmol})$, bpy-ph-B(OR $)_{2}$ [12] (185 mg, $\left.0.52 \mathrm{mmol}\right)$, $\mathrm{Na}_{2} \mathrm{CO}_{3} 0.5 \mathrm{M}(10 \mathrm{~mL}, 5 \mathrm{mmol})$, and $\mathrm{Pd}\left(\mathrm{PPh}_{3}\right)_{4}(0.04 \mathrm{~mol} \%)$. The crude product was used in the next step without further purification (yield: $144 \mathrm{mg}, 80 \%$ ).

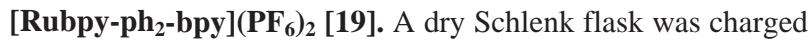
with [Rubpy-ph-Br] $\left(\mathrm{PF}_{6}\right)_{2}$ (140 mg, $\left.0.14 \mathrm{mmol}\right)$, bpy-ph-B(OR) [12] (70 mg, $0.20 \mathrm{mmol}), \mathrm{K}_{2} \mathrm{CO}_{3}(94 \mathrm{mg}, 0.68 \mathrm{mmol}$ ), and $20 \mathrm{~mL}$ of DMF. The solution was degassed by the freeze-pump-thaw technique, and $\mathrm{Pd}\left(\mathrm{PPh}_{3}\right)_{4}(0.04 \mathrm{~mol} \%)$ was added. The reaction mixture was heated at $120^{\circ} \mathrm{C}$ for $24 \mathrm{~h}$. The solvent was evaporated under reduced pressure to afford a black solid. The crude product was dissolved in water/acetone $(10: 1,10 \mathrm{~mL})$, and a saturated aqueous solution $(1 \mathrm{~mL})$ of $\mathrm{NH}_{4} \mathrm{PF}_{6}$ was added. The acetone was removed under reduced pressure from the water phase, and the precipitated solid was filtered and washed with water $(2 \times 20 \mathrm{~mL})$ and diethyl ether $(2 \times 10 \mathrm{~mL})$. The crude product was purified on a silica gel column with $\mathrm{MeCN} / \mathrm{H}_{2} \mathrm{O} / \mathrm{MeOH} / \mathrm{KNO}_{3}, 4: 1: 1: 0.1$ as eluent. An orange compound (TLC: $R_{f}=0.20$, support $\mathrm{SiO}_{2}$, solvent $\mathrm{MeCN} / \mathrm{H}_{2} \mathrm{O} / \mathrm{MeOH} / \mathrm{KNO}_{3}, 4: 1: 1: 0.1$, as eluent) was isolated and further purified by preparative thick-layer chromatography $\left(\mathrm{SiO}_{2}, \mathrm{MeCN} / \mathrm{H}_{2} \mathrm{O} / \mathrm{MeOH} / \mathrm{KNO}_{3}, 4: 1: 1: 0.1\right.$, as mobile phase). Recrystallization from acetone/hexane yielded a crystalline orange powder (yield: $121 \mathrm{mg}, 74 \%) .{ }^{1} \mathrm{H}$ NMR $\left(300 \mathrm{MHz}\right.$, acetone- $d_{6}$ ): $\delta=8.81(\mathrm{dd}, J=0.9 \mathrm{~Hz}, 2.1 \mathrm{~Hz}, 1 \mathrm{H}), 8.76(\mathrm{~d}, J=0.9 \mathrm{~Hz}, 4.8$ $\mathrm{Hz}, 1 \mathrm{H}), 8.73$ (ddd, $J=0.9 \mathrm{~Hz}, 1.8 \mathrm{~Hz}, 4.8 \mathrm{~Hz}, 1 \mathrm{H}), 8.54$ (dt, $J=$ $1.2 \mathrm{~Hz}, 8.1 \mathrm{~Hz}, 1 \mathrm{H}), 7.99-7.88(\mathrm{~m}, 5 \mathrm{H}), 7.75$ (dd, $J=1.8 \mathrm{~Hz}, 5.4$ $\mathrm{Hz}, 1 \mathrm{H}) 7.45$ (ddd, $J=1.2 \mathrm{~Hz}, 5.0 \mathrm{~Hz}, 1 \mathrm{H}$ ). HRMS (ESI), $m / z:\left[\mathrm{M}-2 \mathrm{PF}_{6}\right]^{2+}$ calcd for $\mathrm{C}_{52} \mathrm{H}_{38} \mathrm{~N}_{8} \mathrm{Ru}(102)$ : 438.1126; found: 438.1135 .

[Ru-ph $\left.\mathbf{2}_{\mathbf{2}}-\mathbf{R u}\right]\left(\mathbf{P F}_{\mathbf{6}}\right)_{\mathbf{4}}$ [1]. To a solution of $\mathrm{Ru}(\mathrm{bpy})_{2} \mathrm{Cl}_{2}(11 \mathrm{mg}$, $0.02 \mathrm{mmol})$ in ethylene glycol $(5 \mathrm{~mL})$ with $5 \%$ water content, [Rubpy-ph $_{2}$-bpy $]^{2+}$ [19] $(20 \mathrm{mg}, 0.017 \mathrm{mmol})$ was added. The suspension was repeatedly heated three times for two minutes in a modified microwave oven $(450 \mathrm{~W})$. The solvents were removed under reduced pressure. The solid residue was dissolved in water $(10 \mathrm{~mL})$. The water phase was washed with $\mathrm{CH}_{2} \mathrm{Cl}_{2}(3 \times 5 \mathrm{~mL})$ in order to remove starting materials. Evaporation of the water phase gave a red solid that was purified by silica gel column chromatography $\left(\mathrm{MeCN} / \mathrm{H}_{2} \mathrm{O} / \mathrm{MeOH} / \mathrm{NaCl}, 4: 1: 1: 0.1\right)$. After evaporation of the organic solvents, the desired product was precipitated from the remaining water-layer by adding $\mathrm{NH}_{4} \mathrm{PF}_{6}(100 \mathrm{mg})$. The orange precipitate was filtered over Celite and washed several times with water $(2 \times 20 \mathrm{~mL})$ and diethyl ether $(2 \times 10 \mathrm{~mL})$. Finally the compound was eluted from Celite with acetone. Evaporation of the solvent yielded an orange solid (yield: $25 \mathrm{mg}, 78 \%$ ). ${ }^{1} \mathrm{H}$ NMR $\left(300 \mathrm{MHz}, \mathrm{CD}_{3} \mathrm{CN}\right): \delta=8.83(\mathrm{~s}, 2 \mathrm{H}), 8.75(\mathrm{~d}, J=8.1 \mathrm{~Hz}, 2 \mathrm{H})$, $8.55(\mathrm{~m}, 8 \mathrm{H}), 8.15-8.07(\mathrm{~m}, 10 \mathrm{H}), 8.06(\mathrm{~d}, J=8.6 \mathrm{~Hz}, 4 \mathrm{H}), 8.00$ $(\mathrm{d}, J=8.6 \mathrm{~Hz}, 4 \mathrm{H}), 7.85(\mathrm{~d}, J=6.1 \mathrm{~Hz}, 2 \mathrm{H}), 7.83-7.77(\mathrm{~m}$, $10 \mathrm{H}), 7.74(\mathrm{dd}, J=6.1 \mathrm{~Hz}, 2.0 \mathrm{~Hz}, 2 \mathrm{H}), 7.48-7.42(\mathrm{~m}, 10 \mathrm{H}) .{ }^{13} \mathrm{C}$ NMR (100 MHz, $\left.\mathrm{CD}_{3} \mathrm{CN}\right): \delta=157.9,157.4,152.1,149.1,141.9$, 140.0, 138.2, 135.7, 128.5, 128.0, 125.1, 124.9, 124.7, 122.1. MS $($ ESI, $m / z): 790.13\left(\mathrm{M}-2 \mathrm{PF}_{6}\right), 478.09\left(\mathrm{M}^{+}-3 \mathrm{PF}_{6}\right), 322.58\left(\mathrm{M}^{+}-\right.$
$4 \mathrm{PF}_{6}$ ). HRMS (ESI), m/z: $\left[\mathrm{M}-4 \mathrm{PF}_{6}\right]^{4+}$ calcd for $\mathrm{C}_{72} \mathrm{H}_{54} \mathrm{~N}_{12} \mathrm{Ru}-$ $(102)_{2}$ : 322.5665; found: 332.5670 .

[Ru-ph $\mathbf{3}-\mathbf{R u}]\left(\mathbf{P F}_{\mathbf{6}}\right)_{\mathbf{4}}$ [3]. [Rubpy-ph-Br] ${ }^{2+}[\mathbf{1 8}](52 \mathrm{mg}, 5.1 \times$ $\left.10^{-5} \mathrm{~mol}\right), 4,4^{\prime}$-phenyldiboronic acid $\left(4.2 \mathrm{mg}, 2.55 \times 10^{-5} \mathrm{~mol}\right)$, and $\mathrm{K}_{2} \mathrm{CO}_{3}\left(35 \mathrm{mg}, 2.6 \times 10^{-4} \mathrm{~mol}\right)$ were dissolved in DMF $(10$ $\mathrm{mL}) . \mathrm{Pd}\left(\mathrm{PPh}_{3}\right)_{4}\left(4 \mathrm{mg}, 3.5 \times 10^{-6} \mathrm{~mol}\right)$ was added to the degassed solution, and the reaction mixture was heated to $95^{\circ} \mathrm{C}$. After $16 \mathrm{~h}$ the solvent was removed under vacuum $\left(100^{\circ} \mathrm{C}\right)$, and the residue was purified as described before for $\left[\mathrm{Ru}-\mathrm{ph}_{2}-\mathrm{Ru}\right]\left(\mathrm{PF}_{6}\right)_{4}$. Evaporation of the solvent yielded an orange solid (yield: $42 \mathrm{mg}, 78 \%$ ). ${ }^{1} \mathrm{H}$ NMR (300 MHz, $\left.\mathrm{CD}_{3} \mathrm{CN}\right): \delta=8.82(\mathrm{~s}, 2 \mathrm{H}), 8.73(\mathrm{~d}, J=8.0 \mathrm{~Hz}$, $2 \mathrm{H}), 8.54(\mathrm{dd}, J=8.3 \mathrm{~Hz}, J=2.0 \mathrm{~Hz}, 8 \mathrm{H}), 8.18-7.96(\mathrm{~m}, 18 \mathrm{H})$, $7.92(\mathrm{~s}, 4 \mathrm{H}), 7.88-7.72(\mathrm{~m}, 14 \mathrm{H}), 7.52-7.40(\mathrm{~m}, 10 \mathrm{H})$. HRMS (ESI), $m / z$ : $\left[\mathrm{M}-4 \mathrm{PF}_{6}\right]^{4+}$ calcd for $\mathrm{C}_{78} \mathrm{H}_{58} \mathrm{~N}_{12} \mathrm{Ru}(102)_{2}$ : 341.5743; found: 341.5751 .

[Ru-ph $\mathbf{4}-\mathbf{R u}]\left(\mathbf{P F}_{\mathbf{6}}\right)_{\mathbf{4}}$ [5]. A solution of [Rubpy-ph-Br] ${ }^{2+}[\mathbf{1 8}](310$ $\mathrm{mg}, 0.30 \mathrm{mmol}), 4,4^{\prime}$-biphenyldiboronic acid (37 mg, $\left.0.15 \mathrm{mmol}\right)$ and $\mathrm{Na}_{2} \mathrm{CO}_{3} \cdot 10 \mathrm{H}_{2} \mathrm{O}(127 \mathrm{mg}, 0.92 \mathrm{mmol})$ in DMF $(10 \mathrm{~mL})$ was degassed by the freeze-pump-thaw technique. Subsequently, Pd$\left(\mathrm{PPh}_{3}\right)_{4}\left(10 \mathrm{mg}, 4.6 \times 10^{-3} \mathrm{mmol}\right)$ was added, and the reaction mixture was heated to $90{ }^{\circ} \mathrm{C}$. After $16 \mathrm{~h}$ the solvent was removed under vacuum $\left(100{ }^{\circ} \mathrm{C}\right)$, and the residue was purified as described before for $\left[\mathrm{Ru}-\mathrm{ph}_{2}-\mathrm{Ru}\right]\left(\mathrm{PF}_{6}\right)_{4}$. The reaction yields an orange-red solid (yield: $242 \mathrm{mg}, 80 \%) .{ }^{1} \mathrm{H}$ NMR $\left(300 \mathrm{MHz}, \mathrm{CD}_{3} \mathrm{CN}\right): \delta=$ $8.81(\mathrm{~s}, 2 \mathrm{H}), 8.73(\mathrm{~d}, J=8.0 \mathrm{~Hz}, 2 \mathrm{H}), 8.54(\mathrm{dd}, J=8.3 \mathrm{~Hz}, 2.0$ $\mathrm{Hz}, 8 \mathrm{H}), 8.20-7.68$ (br m, 40H), 7.52-7.40 (m, 10H). HRMS (ESI), $m / z: \quad\left[\mathrm{M}-4 \mathrm{PF}_{6}\right]^{4+}$ calcd for $\mathrm{C}_{85} \mathrm{H}_{62} \mathrm{~N}_{12} \mathrm{Ru}(101) \mathrm{Ru}(102)$ : 360.3324; found: 360.3336 .

[Ru-ph $5-\mathbf{R u}]\left(\mathbf{P F}_{\mathbf{6}}\right)_{\mathbf{4}}$ [7]. This compound was prepared according to the same conditions as described above for $\left[\mathrm{Ru}-\mathrm{ph}_{4}-\mathrm{Ru}\right]\left(\mathrm{PF}_{6}\right)_{4}$, starting from $100 \mathrm{mg}(0.088 \mathrm{mmol})$ of $\left[\text { Rubpy-ph } \mathrm{p}_{2}-\mathrm{I}\right]^{2+}[\mathbf{2 0}], 70$ $\mathrm{mg}(0.35 \mathrm{mmol})$ of 4,4'-biphenyldiboronic acid, $73 \mathrm{mg}(0.53 \mathrm{mmol})$ of $\mathrm{K}_{2} \mathrm{CO}_{3}$, and $5 \mathrm{mg}(0.004 \mathrm{mmol})$ of $\mathrm{Pd}\left(\mathrm{PPh}_{3}\right)_{4}$ in $20 \mathrm{~mL}$ of DMF, to give $\left[\mathrm{Ru}-\mathrm{ph}_{5}-\mathrm{Ru}\right]\left(\mathrm{PF}_{6}\right)_{4}$, an orange solid (yield: $79 \mathrm{mg}, 77 \%$ ). ${ }^{1} \mathrm{H}$ NMR $\left(400 \mathrm{MHz}, \mathrm{CD}_{3} \mathrm{CN}\right): \delta=8.83(\mathrm{~s}, 2 \mathrm{H}), 8.75(\mathrm{~d}, J=8.1$ $\mathrm{Hz}, 2 \mathrm{H}), 8.55$ (dd, $J=7.6 \mathrm{~Hz}, 8 \mathrm{H}), 8.15-8.07$ (m, 10H), $8.05(\mathrm{~d}$, $J=8.6 \mathrm{~Hz}, 4 \mathrm{H}), 7.99(\mathrm{~d}, J=8.6 \mathrm{~Hz}, 4 \mathrm{H}), 7.90(\mathrm{~d}, J=6.1 \mathrm{~Hz}$, $12 \mathrm{H}), 7.82-7.73(\mathrm{~m}, 14 \mathrm{H}), 7.48-7.42(\mathrm{~m}, 10 \mathrm{H})$. HRMS (ESI), $m / z:\left[\mathrm{M}-4 \mathrm{PF}_{6}\right]^{4+}$ calcd for $\mathrm{C}_{90} \mathrm{H}_{66} \mathrm{~N}_{12} \mathrm{Ru}(101) \mathrm{Ru}(102)$ : 379.3403; found: 379.3409 .

[Ru-Flu-Ru] $\left(\mathbf{P F}_{\mathbf{6}}\right)_{\mathbf{4}}$ [9]. This compound was prepared according to the same conditions as described above for $\left[\mathrm{Ru}-\mathrm{ph}_{4}-\mathrm{Ru}\right]\left(\mathrm{PF}_{6}\right)_{4}$, starting from $100 \mathrm{mg}(9.86 \mathrm{~mol})$ of [Rubpy-ph-Br] ${ }^{2+}[\mathbf{1 8}], 43 \mathrm{mg}$ $\left(4.5 \times 10^{-5} \mathrm{~mol}\right)$ of $[22], 37 \mathrm{mg}\left(2.40 \times 10^{-4} \mathrm{~mol}\right)$ of $\mathrm{K}_{2} \mathrm{CO}_{3}$, and $5 \mathrm{mg}\left(4.5 \times 10^{-6} \mathrm{~mol}\right)$ of $\mathrm{Pd}\left(\mathrm{PPh}_{3}\right)_{4}$ in $20 \mathrm{~mL}$ of $\mathrm{DMF}$, to give an orange solid (yield: $101 \mathrm{mg}, 87 \%) .{ }^{1} \mathrm{H} \mathrm{NMR}\left(300 \mathrm{MHz}, \mathrm{CD}_{3} \mathrm{CN}\right)$ : $\delta=8.87(\mathrm{~s}, 2 \mathrm{H}), 8.78(\mathrm{~d}, J=4.8 \mathrm{~Hz}, 2 \mathrm{H}), 8.58(\mathrm{dd}, J=7.8 \mathrm{~Hz}$, $8 \mathrm{H}), 8.20-8.05(\mathrm{~m}, 18 \mathrm{H}), 8.00-7.93(\mathrm{~m}, 4 \mathrm{H}), 7.90-7.75(\mathrm{~m}, 18 \mathrm{H})$, 7.54-7.42 (m, 10H), $2.02(\mathrm{~m}, 8 \mathrm{H}), 1.23-1.00(\mathrm{~m}, 40 \mathrm{H}), 0.78(\mathrm{t}$, $12 \mathrm{H}), 0.69(\mathrm{~m}, 8 \mathrm{H})$. HRMS (ESI), m/z: $\left[\mathrm{M}-4 \mathrm{PF}_{6}\right]^{4+}$ calcd for $\mathrm{C}_{124} \mathrm{H}_{130} \mathrm{~N}_{12} \mathrm{Ru}(102) \mathrm{Ru}(104)$ : 498.2154; found: 498.2164.

[Osbpy-ph-Br] $\left(\mathbf{P F}_{6}\right)_{4}$ [21]. Os(bpy $)_{2} \mathrm{Cl}_{2}(120.4 \mathrm{mg}, 0.21 \mathrm{mmol})$ and bpy-ph-Br [11] (50 mg, $0.16 \mathrm{mmol})$ were dissolved in $3 \mathrm{~mL}$ of ethylene glycol. The mixture was placed in a modified microwave oven and irradiated at $450 \mathrm{~W}$ for two minutes and, after a cooling period, for another two minutes. The stage of conversion was checked by TLC, and the reaction mixture was longer irradiated if necessary. The solvent was distilled off under vacuum using a "micro distillation head" at high temperature $\left(90-110{ }^{\circ} \mathrm{C}\right)$. The dark-green compound was dissolved in water $( \pm 20 \mathrm{~mL})$, and the water phase was extracted with chloroform to remove the excess of $\mathrm{Os}(\mathrm{bpy})_{2} \mathrm{Cl}_{2}$. The compound was purified by column chromatography on silica gel using $\mathrm{MeCN} / \mathrm{H}_{2} \mathrm{O} / \mathrm{MeOH} / \mathrm{KNO}_{3}, 4: 1: 1: 0.1$ 
as eluent. The desired compound was collected, and the organic solvents were evaporated. A quantity of $100 \mathrm{mg}$ of $\mathrm{NH}_{4} \mathrm{PF}_{6}$ in 2 $\mathrm{mL}$ of water was added to the remaining water-layer to obtain a dark-green precipitate. The precipitate was filtered over Celite and washed several times with water $(2 \times 20 \mathrm{~mL})$ and diethyl ether $(2$ $\times 10 \mathrm{~mL}$ ). Finally the compound was eluted from Celite with acetone. [Osbpy-ph-Br] $\left(\mathrm{PF}_{6}\right)_{2}$ was obtained as a dark-green powder (yield: $150 \mathrm{mg}, 85 \%) .{ }^{1} \mathrm{H}$ NMR $\left(300 \mathrm{MHz}, \mathrm{CD}_{3} \mathrm{CN}\right): \delta=8.73$ $(\mathrm{s}, 1 \mathrm{H}), 8.69(\mathrm{~d}, J=8.0 \mathrm{~Hz}, 1 \mathrm{H}), 8.58-8.46(\mathrm{~d}, J=8.3 \mathrm{~Hz}, 4 \mathrm{H})$, $7.95-7.82(\mathrm{~m}, 5 \mathrm{H}), 7.80(\mathrm{~s}, 4 \mathrm{H}), 7.74-7.65(\mathrm{~m}, 6 \mathrm{H}) 7.65(\mathrm{~d}, J=$ $7.5 \mathrm{~Hz}, 1 \mathrm{H}), 7.36-7.27(\mathrm{~m}, 5 \mathrm{H})$ ). HRMS (ESI), $m / z:\left[\mathrm{M}-4 \mathrm{PF}_{6}\right]^{4+}$ calcd for $\mathrm{C}_{36} \mathrm{H}_{27} \mathrm{~N}_{6} \mathrm{Os}(192) \mathrm{Br}(79)$ : 407.0542; found: 407.0534 .

[Os-ph $\left.\mathbf{p}_{2}-\mathbf{O s}\right]\left(\mathbf{P F}_{6}\right)_{4}$ [2]. To a solution of $\mathrm{Os}(\mathrm{bpy})_{2} \mathrm{Cl}_{2}(160 \mathrm{mg}$, $0.28 \mathrm{mmol})$ dissolved in ethylene glycol $(5 \mathrm{~mL})$ with $5 \%$ water content, bpy-ph 2 -bpy [15] (55 mg, $0.13 \mathrm{mmol})$ was added. The suspension was repeatedly heated in a modified microwave oven $(450 \mathrm{~W})$ three times for two minutes and allowed to cool between heating periods. The solvents were removed under reduced pressure to form a solid residue, and redissolved in water $(10 \mathrm{~mL})$. The water phase was washed with $\mathrm{CH}_{2} \mathrm{Cl}_{2}(3 \times 5 \mathrm{~mL})$ in order to remove starting materials. The remaining $\mathrm{CH}_{2} \mathrm{Cl}_{2}$ was removed under reduced pressure from the water phase, $\mathrm{NH}_{4} \mathrm{PF}_{6}(100 \mathrm{mg})$ was added, and the resulting green precipitate was isolated by suction filtration. The crude product was dissolved in acetone (3 $\mathrm{mL}$ ) and purified by silica gel column chromatography using $\mathrm{MeCN} / \mathrm{H}_{2} \mathrm{O} / \mathrm{MeOH} / \mathrm{KNO}_{3}, 4: 1: 1: 0.1$ as eluent. A green band (TLC: $R_{f}=0.32$, support $\mathrm{SiO}_{2}, \mathrm{MeCN} / \mathrm{H}_{2} \mathrm{O} / \mathrm{MeOH} / \mathrm{KNO}_{3}, 4: 1: 1$ : 0.1 , as eluent) was isolated, and the solvents were removed under reduced pressure. The green solid was further purified by preparative plate $\left(\mathrm{SiO}_{2}, \mathrm{MeCN} / \mathrm{H}_{2} \mathrm{O} / \mathrm{MeOH} / \mathrm{KNO}_{3}, 4: 1: 1: 0.1\right.$, as mobile phase). The recrystallization from acetone/diethyl ether yielded a crystalline green powder (yield: $223 \mathrm{mg}, 84 \%) .{ }^{1} \mathrm{H}$ NMR (400 MHz, $\left.\mathrm{CD}_{3} \mathrm{CN}\right): \delta=8.80(\mathrm{~s}, 2 \mathrm{H}), 8.73(\mathrm{~d}, J=8.6 \mathrm{~Hz}, 2 \mathrm{H}), 8.53(\mathrm{dd}, J$ $=7.1 \mathrm{~Hz}, 8 \mathrm{H}), 8.05(\mathrm{~d}, J=8.6 \mathrm{~Hz}, 4 \mathrm{H}), 7.99(\mathrm{~d}, J=8.6 \mathrm{~Hz}, 4 \mathrm{H})$, $7.96-7.88(\mathrm{~m}, 10 \mathrm{H}), 7.77-7.67(\mathrm{~m}, 12 \mathrm{H}), 7.65(\mathrm{dd}, J=6.1 \mathrm{~Hz}$, $2.0 \mathrm{~Hz}, 2 \mathrm{H}), 7.40-7.34(\mathrm{~m}, 10 \mathrm{H}) .{ }^{13} \mathrm{C} \mathrm{NMR}\left(100 \mathrm{MHz}, \mathrm{CD}_{3} \mathrm{CN}\right)$ : $\delta=159.9,159.4,151.3,151.1,148.3,141.9,137.5,135.4,128.6$, $128.3,125.5,125.1,124.9,122.2$. HRMS (ESI), $m / z:\left[\mathrm{M}-4 \mathrm{PF}_{6}\right]^{4+}$ calcd for $\mathrm{C}_{72} \mathrm{H}_{54} \mathrm{~N}_{12} \mathrm{Os}(190) \mathrm{Os}(192)$ : 367.0943 ; found: 367.0949 .

[Os-ph $\mathbf{3}-\mathbf{O s}$ ] $\left(\mathbf{P F}_{\mathbf{6}}\right)_{\mathbf{4}}$ [4]. [Osbpy-ph-Br] ${ }^{2+}$ [21] (33 mg, $2.99 \times$ $\left.10^{-5} \mathrm{~mol}\right), 4,4^{\prime}$-phenyldiboronic acid $\left(2.7 \mathrm{mg}, 1.63 \times 10^{-5} \mathrm{~mol}\right)$, and $\mathrm{K}_{3} \mathrm{PO}_{4}\left(28 \mathrm{mg}, 1.3 \times 10^{-4} \mathrm{~mol}\right)$ were dissolved in a mixture of ethanol $(4 \mathrm{~mL})$ and dioxane $(5 \mathrm{~mL}) . \mathrm{Pd}\left(\mathrm{PPh}_{3}\right)_{4}(3 \mathrm{mg}, 2.4 \times$ $\left.10^{-6} \mathrm{~mol}\right)$ was added to the degassed solution and the reaction mixture was heated to $95^{\circ} \mathrm{C}$. After $16 \mathrm{~h}$ the solvents were removed under vacuum $\left(100^{\circ} \mathrm{C}\right)$, and the residue was purified as described before for $\left[\mathrm{Ru}-\mathrm{ph}_{2}-\mathrm{Ru}\right]\left(\mathrm{PF}_{6}\right)_{4}$. A dark-green solid was obtained (yield: $24 \mathrm{mg}, 70 \%) .{ }^{1} \mathrm{H} \mathrm{NMR}\left(300 \mathrm{MHz}, \mathrm{CD}_{3} \mathrm{CN}\right): \delta=8.81$ (s, $2 \mathrm{H}), 8.72(\mathrm{~d}, J=7.8 \mathrm{~Hz}, 2 \mathrm{H}), 8.55-8.51(\mathrm{~m}, 8 \mathrm{H}), 8.05-7.88(\mathrm{~m}$, 21H), 7.76-7.64 (m, 15H), 7.39-7.33 (m, 10H). HRMS (ESI), $m / z:\left[\mathrm{M}-4 \mathrm{PF}_{6}\right]^{4+}$ calcd for $\mathrm{C}_{78} \mathrm{H}_{58} \mathrm{~N}_{12} \mathrm{Os}(190) \mathrm{Os}(192)$ : 386.1021 ; found: 386.1025 .

[Os-ph $\left.\mathbf{4}_{\mathbf{4}} \mathbf{- O s}\right]\left(\mathbf{P F}_{\mathbf{6}}\right)_{\mathbf{4}}$ [6]. To a solution of $\mathrm{Os}(\mathrm{bpy})_{2} \mathrm{Cl}_{2}(20 \mathrm{mg}$, $0.03 \mathrm{mmol})$, dissolved in ethylene glycol $(5 \mathrm{~mL})$ with $5 \%$ water

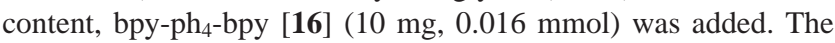
suspension was homogenized in an ultrasonic bath and then heated in a modified microwave oven $(3 \times 2 \mathrm{~min}, 450 \mathrm{~W})$. Water $(10$ $\mathrm{mL}$ ) was added to the reaction solution, and the insoluble part was filtered off over Celite; $\mathrm{NH}_{4} \mathrm{PF}_{6}(100 \mathrm{mg})$ was then added, and the resulting green precipitate was isolated by suction filtration, washed several times with water, and then with diethyl ether. The crude product was dissolved in acetone $(3 \mathrm{~mL})$ and purified by silica gel column chromatography with $\mathrm{MeCN} / \mathrm{H}_{2} \mathrm{O} / \mathrm{MeOH} / \mathrm{KNO}_{3}, 4: 1: 1: 0.1$ as eluent. Recrystallization from acetone/diethyl ether yielded a crystalline green powder (yield: $9 \mathrm{mg}, 24 \%) .{ }^{1} \mathrm{H}$ NMR $(400 \mathrm{MHz}$, $\left.\mathrm{CD}_{3} \mathrm{CN}\right): \delta=8.81(\mathrm{~s}, 2 \mathrm{H}), 8.73(\mathrm{~d}, J=8.1 \mathrm{~Hz}, 2 \mathrm{H}), 8.53(\mathrm{dd}, J$ $=7.6 \mathrm{~Hz}, 8 \mathrm{H}), 8.04(\mathrm{~d}, J=8.6 \mathrm{~Hz}, 4 \mathrm{H}), 7.98(\mathrm{~d}, J=8.6 \mathrm{~Hz}, 4 \mathrm{H})$, $7.96-7.87(\mathrm{~m}, 18 \mathrm{H}), 7.77-7.67(\mathrm{~m}, 12 \mathrm{H}), 7.65(\mathrm{dd}, J=2.0 \mathrm{~Hz}$, $6.1 \mathrm{~Hz}, 2 \mathrm{H}), 7.39-7.33(\mathrm{~m}, 10 \mathrm{H}) .{ }^{13} \mathrm{C}$ NMR $\left(100 \mathrm{MHz}, \mathrm{CD}_{3} \mathrm{CN}\right)$ : $\delta=159.8,159.4,151.3,151.1,137.6,137.4,128.6,128.4,128.1$, 127.9, 124.9, 122.2. HRMS (ESI), $\mathrm{m} / \mathrm{z}:\left[\mathrm{M}-4 \mathrm{PF}_{6}\right]^{4+}$ calcd for $\mathrm{C}_{84} \mathrm{H}_{62} \mathrm{~N}_{12} \mathrm{Os}(190) \operatorname{Os}(192)$ : 405.1099 ; found: 405.1107

[Os-ph $\left.{ }_{5}-\mathbf{O s}\right]\left(\mathbf{P F}_{6}\right)_{4}[\mathbf{8}]$. This compound was prepared by the same procedure as that used for [Os-ph $-\mathrm{Os}]\left(\mathrm{PF}_{6}\right)_{4}$ with $\mathrm{Os}(\mathrm{bpy})_{2} \mathrm{Cl}_{2}(66$ $\mathrm{mg}, 0.12 \mathrm{mmol}$ ) and bpy-ph ${ }_{5}$-bpy [17] (40 mg, $\left.0.06 \mathrm{mmol}\right)$. The reaction yielded a crystalline dark-green powder (yield: $27 \mathrm{mg}$, 20\%). ${ }^{1} \mathrm{H}$ NMR (400 MHz, $\left.\mathrm{CD}_{3} \mathrm{CN}\right): \delta=8.81(\mathrm{~s}, 2 \mathrm{H}), 8.73(\mathrm{~d}, J$ $=8.6 \mathrm{~Hz}, 2 \mathrm{H}), 8.53(\mathrm{dd}, J=8.1 \mathrm{~Hz}, 8 \mathrm{H}), 8.04(\mathrm{~d}, J=8.6 \mathrm{~Hz}$, $4 \mathrm{H}), 7.98(\mathrm{~d}, J=8.6 \mathrm{~Hz}, 4 \mathrm{H}), 7.90(\mathrm{~d}, J=7.1 \mathrm{~Hz}, 20 \mathrm{H}), 7.78-$ $7.67(\mathrm{~m}, 14 \mathrm{H}), 7.66(\mathrm{dd}, J=7.1 \mathrm{~Hz}, 2.0 \mathrm{~Hz}, 2 \mathrm{H}), 7.39-7.32(\mathrm{~m}$, $10 \mathrm{H})$. HRMS (ESI), $m / z$ : $\left[\mathrm{M}-4 \mathrm{PF}_{6}\right]^{4+}$ calcd for $\mathrm{C}_{90} \mathrm{H}_{66} \mathrm{~N}_{12} \mathrm{Os}(190)$ Os(192): 424.1178; found: 424.1188.

[Os-Flu-Os] $\left(\mathbf{P F}_{6}\right)_{4}$ [10]. This compound was prepared according to the same conditions as those described above for [Ru-ph- $\mathrm{Ru}$ $\left(\mathrm{PF}_{6}\right)_{4}$, starting from $80 \mathrm{mg}\left(7.25 \times 10^{-5} \mathrm{~mol}\right)$ of [Osbpy-ph-Br] $]^{2+}$ [21], $35 \mathrm{mg}\left(3.63 \times 10^{-5} \mathrm{~mol}\right)$ of [22], $60 \mathrm{mg}\left(2.40 \times 10^{-4} \mathrm{~mol}\right)$ of $\mathrm{K}_{2} \mathrm{CO}_{3}$, and $8 \mathrm{mg}\left(7.25 \times 10^{-6} \mathrm{~mol}\right)$ of $\mathrm{Pd}\left(\mathrm{PPh}_{3}\right)_{4}$ in $20 \mathrm{~mL}$ of $\mathrm{DMF}$, to give a dark-green solid (yield: $65 \mathrm{mg}, 65 \%$ ). ${ }^{1} \mathrm{H} \mathrm{NMR}$ $\left(300 \mathrm{MHz}, \mathrm{CD}_{3} \mathrm{CN}\right): \delta=8.81(\mathrm{~s}, 2 \mathrm{H}), 8.73(\mathrm{~d}, J=8.0 \mathrm{~Hz}, 2 \mathrm{H})$, $8.58-8.48(\mathrm{~m}, 8 \mathrm{H}), 8.12-7.88(\mathrm{~m}, 18 \mathrm{H}), 7.86-7.62(\mathrm{~m}, 22 \mathrm{H})$, 7.44-7.32 (m, 10H), $2.02(\mathrm{~m}, 8 \mathrm{H}), 1.23-1.00(\mathrm{~m}, 40 \mathrm{H}), 0.78(\mathrm{t}$, $12 \mathrm{H}), 0.69(\mathrm{~m}, 8 \mathrm{H})$. HRMS (ESI), $m / z:\left[\mathrm{M}-4 \mathrm{PF}_{6}\right]^{4+}$ calcd for $\mathrm{C}_{124} \mathrm{H}_{130} \mathrm{~N}_{12} \mathrm{Os}(190) \mathrm{Os}(192)$ : 542.2430; found: 542.2427 .

\section{Conclusions}

We have synthesized and investigated a series of dinuclear homometallic ruthenium and osmium complexes containing $p$-polyphenylene units as spacers. The "chemistry on the complex" approach allows a very easy and straightforward synthesis of the dinuclear ruthenium complexes. However, for the osmium complexes this approach was not suitable and in most of the cases yielded undesired byproducts. Thus a more classical approach had to be used for the osmium dinuclear homometallic complexes involving the complexation of the bridging ligand to $\left[\mathrm{Os}(\mathrm{bpy})_{2} \mathrm{Cl}_{2}\right]$. The electrochemical data show that the first reduction takes place on the bridging bipyridine ligand. The photophysical data indicate in fact that the lowest excited state involves the bpy of the bridging ligand. A weak interaction between the two metal centers exists in the ground state. Time-resolved emission and transient absorption spectroscopy reveal that in the excited state the electronic density is delocalized over the $p$-phenylene spacers. Such a strong directionality in the excitation could be used for vectorial processes.

Acknowledgment. This research was supported by Philips Research (Contract RWC-061-JR-00084-jr) and the European Union (MWFM G5RD-CT-2002-00776).

Supporting Information Available: Crystallographic data including atomic positions and displacement parameters (cif) and mass analysis data. This material is available free of charge via the Internet at http://pubs.acs.org.

IC0483141 